\title{
Mammalian Faunal Zones of the Bridger Middle Eocene
}

SMITHSONIAN CONTRIBUTIONS TO PALEOBIOLOGY - NUMBER 26 


\title{
SERIAL PUBLICATIONS OF THE SMITHSONIAN INSTITUTION
}

The emphasis upon publications as a means of diffusing knowledge was expressed by the first Secretary of the Smithsonian Institution. In his formal plan for the Institution, Joseph Henry articulated a program that included the following statement: "It is proposed to publish a series of reports, giving an account of the new discoveries in science, and of the changes made from year to year in all branches of knowledge." This keynote of basic research has been adhered to over the years in the issuance of thousands of titles in serial publications under the Smithsonian imprint, commencing with Smithsonian Contributions to Knowledge in 1848 and continuing with the following active series:

$$
\begin{aligned}
& \text { Smithsonian Annals of Flight } \\
& \text { Smithsonian Contributions to Anthropology } \\
& \text { Smithsonian Contributions to Astrophysics } \\
& \text { Smithsonian Contributions to Botany } \\
& \text { Smithsonian Contributions to the Earth Sciences } \\
& \text { Smithsonian Contributions to Paleobiology } \\
& \text { Smithsonian Contributions to Zoology } \\
& \text { Smithsonian Studies in History and Technology }
\end{aligned}
$$

In these series, the Institution publishes original articles and monographs dealing with the research and collections of its several museums and offices and of professional colleagues at other institutions of learning. These papers report newly acquired facts, synoptic interpretations of data, or original theory in specialized fields. These publications are distributed by mailing lists to libraries, laboratories, and other interested institutions and specialists throughout the world. Individual copies may be obtained from the Smithsonian Institution Press as long as stocks are available.

\author{
S. Dillon Ripley \\ Secretary \\ Smithsonian Institution
}


SMITHSONIAN GONTRIBUTIONS TOPALEOBIOLOGY • NUMBER 26

\title{
Mammalian Faunal Zones of the Bridger Middle Eocene
}

\author{
C. Lewis Gazin
}

ISSUED

JAN 201976

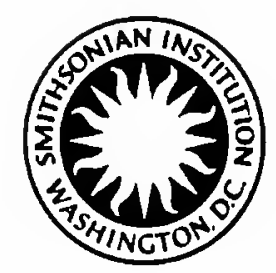

SMITHSONIAN INSTITUTION PRESS

City of Washington

1976 


\section{A B S T R A C T}

Gazin, C. Lewis. Mammalian Faunal Zones of the Bridger Middle Eocene. Smithsonian Contributions to Paleobiology, number 26, 25 pages, 1976.-The zoning arrangement of the Bridger Middle Eocene as defined by W. D. Matthew in his 1909 monograph on the Carnivora and Insectivora of the Bridger Basin included a series of stratigraphic units lettered from $\mathrm{A}$ to $\mathrm{E}$. The type section is in the western part of the basin but correlation of the sequence in the eastern part of the basin erred in that a very large area shown by Matthew as $\mathrm{C}$, or upper Bridger, is actually $\mathrm{B}$, or lower Bridger. As a consequence many of the mammalian remains collected in the eastern part of the basin were attributed to the wrong horizon. This was discovered in my faunal studies and verified by Wilmot Bradley's mapping of the Sage Creek White Layer, which is the base of Bridger $\mathrm{C}$ or upper Bridger.

A faunal list of the Mammalia recognized in the Bridger is given with type localities and their horizons, so far as known, and the number of specimens in the National Museum of Natural History collections from each of the two divisions, lower and upper. Following this a discussion of species is given in which the evidence for any species being restricted to one or the other of the stratigraphic divisions is cited, or such information demonstrating its occurrence in both levels, if this is not indicated by the National Museum of Natural History collections (under the catalog numbers of the old United States National Museum).

The Annotated Bibliography includes references to all papers in which recognized new mammalian families, genera, and species included in the Bridger faunas are described. Also included are papers in which stratigraphic and additional or detailed information on Bridger mammals is provided, with notations as to extent of coverage, and possible errors of detail or interpretation in certain cases.

OfFicial pUblication Date is handstamped in a limited number of initial copies and is recorded in the Institution's annual report, Smithsonian Year. SI Press number 6094. Series cover design: The trilobite Phacops rana Grcen.

Library of Congress Cataloging in Publication Data

Gazin, Charles Lewis, 1904-

Mammalian faumal zones of the Bridger middle Eocene.

(Smithsonian contributions to palcobiology ; no. 26)

Bibliography: p.

Supt. of Docs. no.: S11.30:26

1. Mammals, Fossil. 2. Palcontology-Eocene. 3. Palcontology-The West. I, Title. II. Series: Smithsonian Institution. Smithsonian contributions to Paleobiology ; no. 26.

QE701.S56 no. 26 [QE881] 560'.8s [569'.09787'9] 75-619267 


\section{Contents}

$\begin{aligned} \text { Page } & \text { Pand }\end{aligned}$

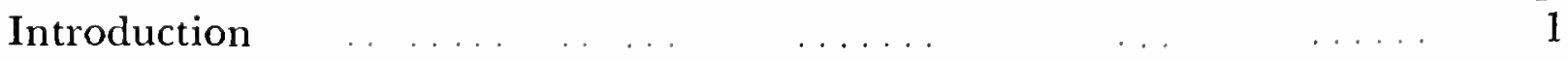

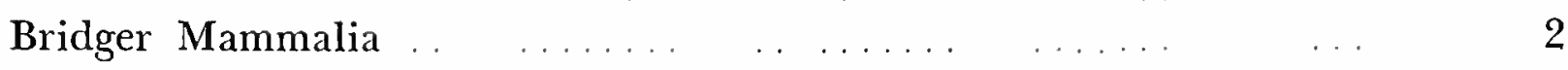

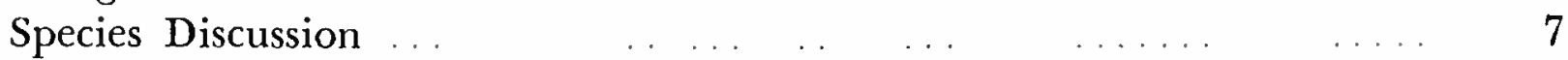

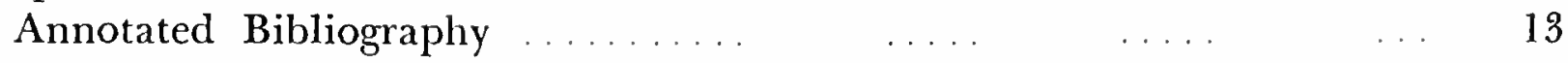





\title{
Mammalian Faunal Zones of the Bridger Middle Eocene
}

\author{
C. Lewis Gazin
}

\section{Introduction}

The outstanding monograph by W. D. Matthew, published in 1909, on the Carnivora and Insectivora of the Bridger Basin included a zoning arrangement based on field work done by Matthew and Walter Granger in 1902 and 1904. They defined a sequence of stratigraphic units lettered from $\mathrm{A}$ to $\mathrm{E}$ with the type section essentially in the western part of the basin. The units were defined, except for A, by prominent and widespread ash layers. Unfortunately, in correlating the sequence on the eastern side of the basin across the higher central tableland, they erred in assigning to Bridger $\mathrm{C}$ a large area of badlands that actually represent Bridger $\mathbf{B}$. This became evident to me in comparisons of faunal materials, particularly of Hyopsodus, from various localities around the basin, and was so reported (Gazin, 1959:136).

In consultation with Wilmot Bradley of the U.S. Geological Survey, who had just finished mapping the Eocene beds in a large portion of southwestern Wyoming and adjacent parts of Colorado and Utah, he showed me his field map, which included precise location of the Sage Creek White Layer of Matthew, that defines the base of Bridger C. It shows clearly the wide distribution of lower Bridger in the eastern part of the basin, which the map published by Matthew shows as Bridger C. Bradley's completed map was published as a part of a

C. Lewis Gazin, Department of Paleobiology, National Museum of Natural History, Smithsonian Institution, Washington, D.C. 20560.
Geological Survey Professional Paper (496-A) in 1964.

The Sage Creek White Layer forms the cap rock of the mesalike uplands of the central part of the basin, extending north from Cedar Mountain to near the Lincoln Highway. It should be further noted that there is essentially no collecting ground for upper Bridger mammals above the Sage Creek White Layer to the north of the northerly slopes of Sage Creek Mountain, Cedar Mountain, and Twin Buttes, at least as far north and east as the Green River, although much farther north the upper beds have been preserved near the Continental Fault in the Tabernacle Butte area. The Sage Creek White Layer extends between Cedar Mountain and Twin Buttes at a level very little below the saddle between these two mountains so that Bridger $\mathbf{B}$ forms the more widespread collecting ground around the lower slopes to the north and east of Twin Buttes. The $\mathrm{B}$ horizon also extends around the south side of Twin Buttes and westward toward the town of Burnt Fork, near which the Sage Creek White Layer crosses Henry's Fork. In this area Bridger B is relatively thin as it tapers rapidly to the south between the Sage Creek White Layer and the underlying Green River beds.

The Sage Creek White Layer is the most important of the white layers named by Matthew, as it defines the boundary between upper and lower Bridger. Moreover, it is essentially different than the other white layers named by Matthew, such as the Lone Tree White Layer, in that besides containing appreciable volcanic ash it has a more lacustrine appearance, particularly toward the east, 
resembling in some ways the Tipton Tongue of the Green River beds. This may well account for the significant faunal change that occurs at this horizon, where little or no change is noticeable with respect to the other ash layers.

Bridger $\mathrm{A}$ as a distinct unit is not clearly defined as separate from Bridger $\mathrm{B}$. Bridger $\mathrm{D}$, defined below by the base of the Lone Tree White Layer, shows no significant faunal differences from Bridger $\mathrm{C}$, and Bridger $\mathrm{E}$ is essentially barren of fossil mammals. As a consequence there is little of significance in the zoning of the Bridger for purposes of mammalian paleontology other than the distinction of upper and lower. This was early recognized, and in $1934 \mathrm{H}$. E. Wood in his paper on the Hyrachyidae designated the lower Bridger ( $A$ and $B$ ) as the Black's Fork member and the upper Bridger (C and $\mathrm{D})$ as the Twin Buttes member. The name designating the lower Bridger is entirely appropriate. The selection of the name Twin Buttes for the upper member, however, was somewhat unfortunate because of the extent of lower Bridger beds around the lower slopes of Twin Buttes.

Because of this error in stratigraphic correlation much of the Bridger material collected by Matthew and others may be incorrectly zoned, unless the localities are in the type section in the western part of the basin and clearly designated. As a consequence I have restricted my following tabulation of the number of specimens of the various Bridger species to the materials in the National Museum of Natural History (NMNH). These include C. W. Gilmore's 1930 collection, which was made only in the type section, and my parties' collections made during 11 different field seasons between 1940 and
1969. Since most of the types were collected by parties from other museums in earlier years, their horizon is indicated by locality name, if given, as well as horizon, if this is evident. The number of specimens of each species in the National Museum of Natural History is given in the horizon columns under the acronym of the old United States Na. tional Museum (USNM).

In the classification arrangement in general I have followed the authoritative work of George Simpson (1945) but with later modifications as seem appropriate, and more detailed arrangements in the lower categories by various workers as noted below. The Marsupialia follows Simpson's study (1928). For the classification of the Insectivora I have relied on various papers by Simpson, Robinson, and McKenna in revisions of Matthew's study (1909B). The Primates and Tillodontia are arranged according to my own $(1958,1953)$ investigations. The Taeniodonta and Pholidota follow Simpson (1945, 1931), but the latter as modified by Emry (1970). The Rodentia are essentially as arrranged by Robert Wilson (1938) and Albert Wood (1962). The Carnivora follows Matthew closely, with certain modifications I (1968) have introduced. The Condylarthra are as arranged by me (1968). The Dinocerata follows Wheeler's (1961) revision. The classification of the Perissodactyla follows the studies of several authorities, including Osborn (1929), Peterson (1919), H. E. Wood (1934), and Kitts (1957), but with modifications, or reductions in species, such as the rhinos, resulting from my own study. The Artiodactyla arrangement is based largely on my own studies, and those of Sinclair (1914).

\section{Bridger Mammalia}

(type localities in parentheses)

\begin{tabular}{|c|c|c|c|}
\hline & \multirow[t]{2}{*}{$\begin{array}{c}\text { Type } \\
\text { horizon }\end{array}$} & \multicolumn{2}{|c|}{$\begin{array}{l}\text { USNM } \\
\text { referred }\end{array}$} \\
\hline & & L & $\mathbf{U}$ \\
\hline \multicolumn{4}{|l|}{ Marsupialia } \\
\hline \multicolumn{4}{|l|}{ Didelphidae Gray, 1821} \\
\hline \multicolumn{4}{|l|}{ Peratherium Aymard, 1850} \\
\hline P. marsupium (Troxell), 1923d & ? & 6 & 2 \\
\hline P. innominatum (Simpson), 1928b (Millersville) & $\mathbf{L}$ & 4 & 3 \\
\hline P. knighti McGrew, 1959 (Tabernacle Butte) & $\mathbf{U}$ & - & - \\
\hline \multicolumn{4}{|l|}{ Insectivora } \\
\hline $\begin{array}{c}\text { Palaeoryctidac(?) Simpson, 1931b } \\
\text { Didelphodus Cope, 1882b }\end{array}$ & & & \\
\hline
\end{tabular}


D. altidens (Marsh), 1872 (near Henry's Fork)

Leptictidae Gill, 1872

Hypictops Gazin, 1949

H. syntaphus Gazin, 1949 (north of Lone Tree)

Palaeictops Matthew, 1899

P. bridgeri (Simpson), 1959b (Tabernacle Butte)

Erinaceidae Bonaparte, 1838

Scenopagus McKenna \& Simpson, 1959

S. priscus (Marsh), 1872) (near Henry's Fork)

S. edenensis (McGrew), 1959 (Eden Valley)

Centetodon Marsh, 1872

C. pulcher Marsh, 1872 (near Henry's Fork)

C.(?) bacchanalis (McGrew), 1959 (Tabernacle Butte)

Adapisoricidae Schlosser, 1887

Entomolestes Matthew, 1909b

E. grangeri Matthew, 1909b (Grizzly Buttes)

Talpavus Marsh 1872

T. nitidus Marsh, 1872 (near Henry's Fork)

Nyctitheriidae Simpson, 1928a

Nyctitherium Marsh, 1872

N. velox Marsh, 1872 (near Henry's Fork)

N. serotinum (Marsh), 1872 (Grizzly Buttes)

N. dasypelix (Matthew), 1909b (Grizzly Buttes)

Pontifactor West, 1974

$P$. bestiola West, 1974 (Henry's Fork Divide)

Pantolestidae Cope, 1884

Pantolestes Cope, $1872 \mathrm{~b}$

$P$. longicaudus Cope, 1872 (Black's Fork)

$P$. elegans (Marsh), 1872 (near Henry's Fork)

$P$. natans Matthew, 1909b

$P$. phocipes Matthew, $1909 \mathrm{~b}$

$P$. intermedius Matthew, $1909 \mathrm{~b}$

Microsyopsidae Osborn, 1892

Microsyops Leidy, 1872a

M. elegans (Marsh), 187la (Grizzly Buttes)

M. annectens (Marsh), 1872 (near Henry's Fork)

M. schlosseri Wortman, 1903 (Henry's Fork)

Apatemyidae Matthew, 1909b

Apatemys Marsh, 1972

A. bellus Marsh 1872 (near Henry's Fork)

A. bellulus Marsh 1872 (near Henry's Fork)

$A$. rodens Troxell $1923 \mathrm{C}$

\section{Primates}

Notharctidae Trouessart, 1879

Notharctus Leidy, 1870c

N. tenebrosus Leidy, 1870c (Black's Fork)

$N$. robustior Leidy, 1872b (Henry's Fork)

Smilodectes Wortman, 1903

S. gracilis (Marsh), $1871 \mathrm{a}$ (Grizzly Buttes)

Type

USNM

horizon

referred

L U

$\mathbf{U}$

$\mathbf{U}$

U $\quad 5 \quad 3$

$4-$

U

U

L

$\mathbf{U}$

U $\quad 5 \quad 3$

L $\quad-\quad$ -

L $\quad 1 \quad-$

$\mathbf{U}$

L $\quad 5 \quad 11$

U 313

U? - -

U - -

L $\quad-\quad-$

L $\quad 96 \quad-$

U $\quad-\quad 9$

U $\quad-\quad 1$

$\begin{array}{lll}\mathrm{U} & 2 & 1\end{array}$

$\begin{array}{lll}\text { U } & 1 & -\end{array}$

? 1

Omomyidae Gazin, 1958

Omomys Leidy, 1869b

O. carteri Leidy, 1869b (Fort Bridger)

L $\quad 136 \quad-$

U $\quad-\quad 64$

L $\quad 110 \quad-$

Hemiacodon Marsh, 1872

H. gracilis Marsh, 1872 (near Henry's Fork)

Washakius Leidy, 1873

$W$. insignis Leidy, 1873

L $\quad 78 \quad 8$

U $\quad-\quad 90$

$? \quad 21 \quad 1$ 


\begin{tabular}{cc}
$\begin{array}{c}\text { Type } \\
\text { horizon }\end{array}$ & $\begin{array}{c}\text { USNM } \\
\text { referred }\end{array}$ \\
\cline { 2 - 2 } $\mathbf{L} U$
\end{tabular}

Anaptomorphidae Cope, 1883

Anaptomorphus Cope, 1872e

A. aemulus Cope, 1872e (Ham's Fork)

A. wortmani Gazin, 1958

Uintanius Matthew, 1915

U. ameghini (Wortman), 1904

Uintasorex Matthew, 1909b

$U$. parvulus Matthew, 1909b (Henry's Fork)

Trogolemur Matthew, 1909b

$T$. myodes Matthew, 1909b (south of Granger)

Tillodontia

Esthonychidae Cope, 1883

Trogosus Leidy, 1871b

T. castoridens Leidy, 1871b (Grizzly Buttes)

T. hyracoides (Marsh), 1873b (Granger Station)

T. latidens (Marsh), 1874b

Tillodon Gazin, 1953

T. fodiens (Marsh), 1875b (Millersville)

Taeniodonta

Stylinodontidae Marsh, 1875a

Stylinodon Marsh, 1874b

S. mirus Marsh, 1874b

Pholidota

Metacheiromyidae Wortman, 1903

Metacheiromys Wortman, 1903

M. marshi Wortman, 1903 (Grizzly Buttes?)

M. tatusia Osborn, 1904 (Grizzly Buttes)

M. dasypus Osborn, 1904 (Grizzly Buttes)

M. osborni Simpson, 1931a (Lone Tree)

Epoicotheriidae Simpson, 1927

Tetrapassalus Simpson, 1959a

T. mckennai Simpson, 1959a (Tabernacle Butte)

T. proius West, 1973c (Sage Creek)

Rodentia

Paramyidae Miller and Gidley, 1918

Paramys Leidy, 1871d

$P$. delicatus Leidy, 1871d (near Fort Bridger) '"

$P$. delicatior Leidy, 1871d (near Fort Bridger)

Thisbemys A. E. Wood, 1959b

T. corrugatus A. E. Wood, 1959b (north of Cedar Mt.)

T. plicatus A. E. Wood, 1962 (Grizzly Buttes)

Leptotomus Matthew, 1910

L. parvus A. E. Wood, 1959b (Grizzly Buttes)

L. bridgerensis A. E. Wood, 1962 (Henry's Fork)

Microparamys A. E. Wood, 1959b

M. minutus (R. W. Wilson), 1937 (Millersvilles)

M. wilsoni A. E. Wood, 1962

M. wyomingensis A. E. Wood, 1959b (Tabernacle Butte)

Reithroparamys Matthew, 1920

R. delicatissimus (Leidy), 1871d (Grizzly Buttes)

R. matthewi A. E. Wood, 1962 (Henry's Fork)

Pseudotomus Cope, 1872b

$P$. hians Cope, 1872b (Cottonwood Creek)

P. robustus (Marsh), 1872 (Grizzly Buttes)

Ischyrotomus Matthew, 1910

I. horribilis A. E. Wood, 1962 (near Grizzly Buttes)

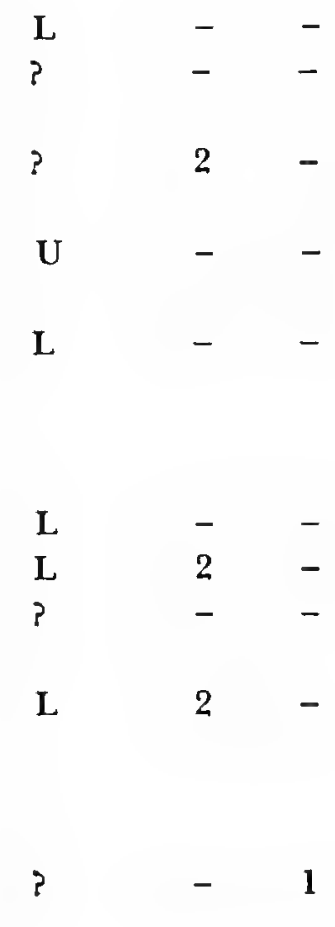

$\begin{array}{lll}\text { L? } & \text { 1 } & - \\ \text { L } & - & - \\ \text { L } & - & - \\ \text { U } & - & -\end{array}$

$\mathrm{U}$

L

$\begin{array}{rrr}\text { L } & 114 & 16 \\ \text { L } & 40 & 18 \\ \text { L } & 7 & 68 \\ \text { L } & 51 & - \\ \text { L } & 39 & - \\ \text { U } & - & 7 \\ \text { L? } & - & - \\ \text { U? } & - & \\ \text { U } & - & \\ & & \\ \text { L } & 17 & - \\ \text { U } & - & - \\ & & - \\ \text { L } & - & - \\ \text { L } & - & 2 \\ \text { L } & 8 & -\end{array}$


I. oweni A. E. Wood, 1962 (north of Twin Buttes)

I. superbus (Osborn, Scott, and Speir), 1878 (Cottonwood Creek)

\begin{tabular}{ccc}
$\begin{array}{c}\text { Type } \\
\text { horizon }\end{array}$ & \multicolumn{2}{c}{$\begin{array}{c}\text { USNM } \\
\text { referred }\end{array}$} \\
\cline { 2 - 3 } L & L & U \\
L & - & - \\
& & \\
L & 21 & - \\
L & 44 & 4 \\
? & 6 & 1 \\
& & \\
L & 175 & 3 \\
L & 7 & - \\
? & - & - \\
& & - \\
U & - & - \\
L & 3 & - \\
U & 1 & 2 \\
? & - & - \\
L? & - & - \\
U & - & -
\end{tabular}

Carnivora, Creodonta

Mesonychidae Cope, 1875

Mesonyx Cope, $1872 \mathrm{a}$

M. obtusidens Cope, 1872a (Cottonwood Creek)

Synoplotherium Cope, 1872d

S. vorax (Marsh), 1876c (Henry's Fork)

Harpagolestes Wortman, 1901

H. macrocephalus Wortman, 1901 (Smith's Fork)

Oxyaenidae Cope, 1877

Patriofelis Leidy, 1870a

$P$. ulta Leidy, 1870a (Fort Bridger)

$P$. ferox (Marsh), 1872 (near Henry's Fork)

Hyaenodontidae Leidy, 1869a

Sinopa Leidy, $1871 \mathrm{~b}$

S. rapax Leidy, $1871 b$ (Grizzly Buttes)

S. pungens (Cope), 1872b (Cottonwood Creek)

S. major Wortman, 1902 (Church Buttes?)

S. minor Wortman, 1902 (Grizzly Buttes)

S. grangeri Matthew, 1906 (Cottonwood Creek)

Tritemnodon Matthew, 1906

T. agilis (Marsh), 1872 (Grizzly Buttes)

Limnocyonidae Gazin, 1946

Limnocyon (Marsh), 1872

L. verus Marsh, 1872 (Grizzly Buttes)

Thinocyon Marsh, 1872

T. velox Marsh, 1872 (Grizzly Buttes)

T. medius (Wortman), 1902 (near Henry's Fork)

T. mustelinus Matthew, 1909b

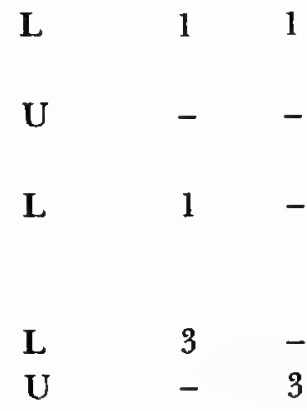

Machaeroides Matthew, 1909b

M. eothen Matthew, $1909 \mathrm{~b}$

$\begin{array}{lrr}\text { L } & 21 & 6 \\ \text { L } & 5 & 2 \\ \text { L? } & - & 3 \\ \text { L } & 16 & - \\ \text { L } & 4 & -\end{array}$

L $\quad 13 \quad-$

L $\quad 17 \quad-$

L $25 \quad-$

U $\quad-\quad 6$

L $15 \quad-$

L $\quad 2 \quad-$

Carnivora, Fissipeda

Miacidae Cope, 1880

Viverravus Marsh, 1872

V. gracilis Marsh, 1872 (Grizzly Buttes)

V. minutus Wortman, 1901 (Dry Creek)

L $\quad 11 \quad 5$

L 3 - 
V. sicarius Matthew, $1909 \mathrm{~b}$

Miacis Cope, $1872 \mathrm{c}$

M. parvivorus Cope, 1872c (Black's Fork)

M. sylvestris (Marsh), 1872 (near Henry's Fork)

M. hargeri (Wortman), 1901 (Henry's Fork)

Oödectes Wortman, 1901

O. herpestoides Wortman, 1901

O. proximus Matthew, 1909b (Grizzly Buttes)

Uintacyon Leidy, 1872d

U. edax Leidy, 1872d

$U$. vorax Leidy, 1872d (Henry's Fork?)

$U$. jugulans Matthew, 1909b (Henry's Fork)

$U$. major Matthew, 1909b

Vulpavus Marsh, 1871b

$V$. palustris Marsh, $1871 \mathrm{~b}$ (near Fort Bridger)

$V$. profectus Matthew, 1909b (Grizzly Buttes)

$V$. ovatus Matthew, 1909b (Little Dry Creek)

Palaearctonyx Matthew, 1909b

P. meadi Matthew, 1909b (Base of Twin Buttes)

Condylarthra

Hyopsodontidae Lydekker, 1889

Hyopsodus Leidy, 1870b

$H$. paulus Leidy, 1870b (near Fort Bridger)

H. minusculus Leidy, 1873 (Little Dry Creek)

H. marshi Osborn, 1902 (Twin Buttes?)

$H$. despiciens Matthew, 1909b (Henry's Fork)

H. lepidus Matthew, 1909b (Henry's Fork)

Dinocerata

Uintatheriidae Flower, 1876

Uintatherium Leidy, 1872c

$U$. anceps (Marsh), 187la (Sage Creek Divide)

Bathyopsis Cope, 1881

B. middleswarti Wheeler, 1961 (near Sandy Creek)

Perissodact yla

Equidae Gray, 1821

Orohippus Marsh, 1872

O. pumilus (Marsh), 1871a (near Marsh's Fork)

O. agilis Marsh, 1873b (Henry's Fork)

O. major Marsh, 1874a (Millersville)

O. sylvaticus (Leidy), 1870d (Henry's Fork)

O. progressus Granger, 1908 (Twin Buttes)

Brontotheriidac Marsh, 1873b

Palaeosyops Leidy, 1870c

P. paludosus Leidy, 1870c (Church Buttes)

$P$. major Leidy, 1871c (Grizzly Buttes)

P. robustus (Marsh), 1872 (near Henry's Fork)

Limnohyops Marsh, 1890

L. laticeps (Marsh), 1872 (Marsh's Fork)

L. priscus Osborn, 1908 (Grizzly Buttes)

Telmatherium Marsh, 1872

T. validum Marsh, 1872 (near Henry's Fork)

T. cultridens (Osborn, Scott and Speir), 1878 (Henry's lork Divide)

Manleoceras Hatcher, 1895

M. manteoceras (Osborn), 1899 (Washakie)

Mesatirhinus Osborn, 1908a

M. megarhinus (Earle), $1891 \mathrm{a}$ (Washakie)

M. petersoni Osborn, 1908a (Cat-tail Spring)

\begin{tabular}{|c|c|c|}
\hline $\begin{array}{c}\text { Type } \\
\text { horizon }\end{array}$ & & $\begin{array}{l}\text { NM } \\
\text { erred }\end{array}$ \\
\hline & $\mathbf{L}$ & $\mathbf{U}$ \\
\hline $\mathbf{L}$ & 2 & - \\
\hline $\mathbf{L}$ & 18 & - \\
\hline $\mathbf{U}$ & - & 1 \\
\hline $\mathbf{U}$ & - & \\
\hline L? & 2 & - \\
\hline $\mathbf{L}$ & - & - \\
\hline$?$ & 2 & - \\
\hline U? & 2 & - \\
\hline$U$ & - & 3 \\
\hline U? & - & - \\
\hline $\mathrm{L}$ & 2 & - \\
\hline L & 5 & - \\
\hline $\mathbf{L}$ & - & - \\
\hline $\mathbf{L}$ & - & - \\
\hline L & 868 & - \\
\hline $\mathbf{L}$ & 80 & - \\
\hline U? & - & 4 \\
\hline $\mathbf{U}$ & - & 162 \\
\hline $\mathrm{U}$ & - & 115 \\
\hline
\end{tabular}

$\mathrm{U} \quad-\quad 7$

L

$\begin{array}{lrr}\mathrm{L} & 56 & - \\ \mathrm{U} & - & - \\ \mathrm{L} & 9 & - \\ \mathrm{U} & - & 9 \\ ? & 11 & 8\end{array}$

$\begin{array}{lrr}\text { L } & 23 & - \\ \text { L } & 7 & - \\ \text { U } & - & 17 \\ \text { L? } & - & - \\ \text { L } & 1 & - \\ \text { U } & - & 2 \\ \text { U } & - & 7 \\ & & \\ & - & 7 \\ & & - \\ & - & 2 \\ \text { U } & - & \end{array}$ 


\begin{tabular}{|c|c|c|c|}
\hline & \multirow[t]{2}{*}{$\begin{array}{c}\text { Type } \\
\text { horizon }\end{array}$} & \multicolumn{2}{|c|}{$\begin{array}{l}\text { USNM } \\
\text { referred }\end{array}$} \\
\hline & & $\mathbf{L}$ & $\mathrm{U}$ \\
\hline \multicolumn{4}{|l|}{ Isectolophidae Peterson, 1919} \\
\hline \multicolumn{4}{|l|}{$\begin{array}{l}\text { Helaletidae Osborn, } 1892 \\
\text { Helaletes Marsh, } 1872\end{array}$} \\
\hline H. nanus (Marsh), 187la (Grizzly Buttes) & $\mathbf{L}$ & 89 & 4 \\
\hline \multicolumn{3}{|l|}{ Dilophodon Scott, 1883} & - \\
\hline D. minusculus Scott, 1883 & $?$ & - & 2 \\
\hline \multicolumn{4}{|l|}{ Hyrachyidac H. E. Wood, 1927} \\
\hline \multicolumn{4}{|l|}{ Hyrachyus Leidy, 1871a } \\
\hline H. modestus (Leidy), 1870b (Smith's Fork) & $\mathbf{L}$ & 55 & 2 \\
\hline H. affinis (Marsh), 1871a (near Marsh's Fork) & $\mathbf{L}$ & 48 & 21 \\
\hline H. eximius Leidy, 1871c (Henry's Fork) & $\mathbf{U}$ & 1 & 7 \\
\hline H. princeps Marsh, 1872 (near Henry's Fork) & $\mathrm{U}$ & - & 3 \\
\hline \multicolumn{4}{|l|}{ Artiodactyla } \\
\hline \multicolumn{4}{|l|}{ Dichobunidae Gill, 1872} \\
\hline $\begin{array}{l}\text { M. cuspidatus Leidy, 1870c (Black's Fork) } \\
\text { Homacodon Marsh, } 1872\end{array}$ & \multicolumn{2}{|c|}{ Homacodon Marsh, 1872} & 3 \\
\hline $\begin{array}{l}\text { H. vagans Marsh, } 1872 \text { (near Henry's Fork) } \\
\text { Antiacodon Marsh, } 1872\end{array}$ & $\mathbf{U}$ & - & 4 \\
\hline A. venustus Marsh, 1872 (near Henry's Fork) & $\mathrm{U}$ & - & 2 \\
\hline A. pygmaeus (Cope), 1872a (Cottonwood Creek) & $\mathbf{L}$ & 20 & - \\
\hline $\begin{array}{l}\text { A. furcatus (Cope), } 1873 \mathrm{a} \text { (Bluffs of upper-Green River) } \\
\text { Helohyus Marsh, } 1872\end{array}$ & \multicolumn{2}{|c|}{ Helohyus Marsh, 1872} & - \\
\hline H. lentus (Marsh), 1871 (Henry's Fork) & $\mathrm{U}$ & - & 1 \\
\hline H. plicodon Marsh, 1872 (Grizzly Buttes) & $\mathbf{L}$ & 6 & 4 \\
\hline H. validus (Marsh), 1872 (near Henry's Fork) & $\mathrm{U}$ & - & - \\
\hline H. milleri Sinclair, 1914 (Henry's Fork) & $\mathbf{U}$ & - & 1 \\
\hline \multicolumn{4}{|l|}{ Lophiohyus Sinclair, 1914} \\
\hline $\begin{array}{l}\text { L. alticeps Sinclair, } 1914 \text { (Twin Buttes) } \\
\text { Neodiacodexis Atkins, } 1970\end{array}$ & $?$ & - & - \\
\hline N. emryi Atkins, 1970 (Tabernacle Butte) & $\mathrm{U}$ & - & - \\
\hline
\end{tabular}

\section{Species Discussion}

The following discussion by species pertains to those forms that appear to be indicative of one or the other horizons, or where the evidence indicated in the foregoing table is inconclusive. Those species represented in the National Museum of Natural History collection by specimens from both horizons as shown above are not included. Otherwise, the sequential arrangement corresponds to the foregoing tabulation. ( $\mathrm{NMNH}=$ National Museum of Natural History; AMNH = American Museum of Natural History.)

Peratherium knighti McGrew: The recorded occurrence of this species is so far only the upper Bridger at Tabernacle Butte.

Didelphodus altidens (Marsh): This species, rep- resented by only a few specimens, seems from the evidence furnished by McKenna (see McKenna et al., 1962) to be upper Bridgerian.

Hypictops syntaphus Gazin: The type and one other known specimen are from the upper Bridger north of Lone Tree.

Palaeictops bridgeri (Simpson): The type from the upper Bridger is the only known specimen.

Scenopagus edenensis (McGrew): Although referred specimens, including the type of Scenopagus mcgrewi, are from the upper Bridger beds at Tabernacle Butte, the type of $S$. edenensis is from nearby Green River beds of lower Bridger equivalence.

Centetodon pulcher Marsh: The type from near Henry's Fork and referred material from Tabernacle Butte are upper Bridgerian, but McKenna 
et al. (1962) referred to the species Hypacodon praecursor, the type of which is from Fort Bridger and may well be lower Bridger. Other Yale specimens of $C$. pulcher were not cited as to horizon.

Centetodon (?) bacchanalis (McGrew): The type and referred material of this species are recorded only from the upper Bridger at Tabernacle Butte.

Entomolestes grangeri Matthew: In Matthew's (1909b) description the type and several referred jaws were stated to be from the lower Bridger but in his faunal list he has the referred material as coming from C? and D. Robinson (1968) states that the type is the only specimen known to him.

Talpavus nitidus Marsh: Marsh cites several specimens but the locality, near Henry's Fork, is given for the type only. Robinson (1968) gives the locality for a referred specimen in the Yale collections as Dry Creek. The upper reaches of Dry Creek are in the upper Bridger but a large area drained by this creek on the east side of the Bridger Basin is lower Bridger, the area indicated by Matthew (1909b) as C.

Nyctitherium serotinum (Marsh): This species may well be restricted to the lower Bridger, but one of the specimens in the Yale collections, according to Robinson (1968), has no locality data.

Nyctitherium dasypelix (Matthew): Both the type and the one known referred specimen are from the lower Bridger at Grizzly Buttes.

Pontifactor bestiola West: The type is from the upper Bridger but the 26 referred specimens in the AMNH collections are stated by West (1974) to be from the lower Bridger. I suspect that the family represented is not the Nyctitheriidae but possibly the Mixodectidae.

Pantolestes natans Matthew: This species was regarded by Matthew as upper Bridgerian, but no localities are given. If either the type or referred material cited as $\mathrm{C}$ came from the eastern part of the basin, both horizons may be represented.

Pantolestes phocipes Matthew: The type is listed as Bridger $\mathrm{D}$ so is surely upper Bridger, but referred material is listed as $\mathrm{C}$ and $\mathrm{D}$. If the $\mathrm{C}$ material is from the eastern side of the basin it may well be lower Bridger.

Pantolestes intermedius Matthew: Localities not given but listed only as $\mathrm{B}$.

Microsyops elegans (Marsh): This species is well represented and appears to be restricted to the lower Bridger.
Microsyops annectens (Marsh): A good number of specimens of this species have been found, all listed as C or D. Wortman (1903) indicated that in the Marsh collection all are from Henry's Fork. Matthew (1909b) lists referred material in the AMNH as from C or D. While some of these might have come from beds on the east side of the basin mislabeled C, it seems improbable as there is no record of an occurrence in the lower beds on the west side, considering the number of specimens found elsewhere.

Microsyops schlosseri Wortman: Wortman (1903) stated that the type and referred specimens in the Marsh collection are all from Henry's Fork. Matthew's (1909b) listing indicates C and D for referred materials in the AMNH. While probably restricted to the upper beds, Matthew's use of C leaves a doubt.

Notharctus tenebrosus Leidy: Robinson's (1957) work as well as mine (1958) has shown that Notharctus tenebrosus is limited to the lower Bridger.

Notharctus robustior Leidy: This species is characteristic of the upper Bridger and equivalent beds as shown by Robinson (1957) and by me (1958).

Smilodectes gracilis (Marsh): This species is actually limited to the lower Bridger and Green River equivalent. Robinson's (1957) including it in the upper Bridger is based on its frequent occurrence around Twin Buttes and elsewhere on the east side of the basin in beds of lower Bridger age, not $\mathrm{C}$ as indicated in Matthew's (1909b) map. The chart shown in my (1958) report is also in error for the same reason.

Hemiacodon gracilis Marsh: So far as known this species is not found in the lower Bridger.

Washakius insignis Leidy: This species is well represented in the lower Bridger, but is scarce in the upper beds. Simpson (in McGrew et al., 1959) has recorded it from the upper beds at Tabernacle Butte.

Anaptomorphus aemulus Cope: A comparatively rare species, but so far recorded only from the lower Bridger.

Anaptomorphus wortmani Gazin: One specimen is known to be lower Bridger, but the type and two others are from unknown localities in the Bridger.

Uintanius ameghini (Wortman): Remains of this species are rare but have been found in both upper and lower beds.

Uintasorex parvulus Matthew: In the Bridger 
Basin this small species, though uncommon, appears restricted to the upper beds.

Trogolemur myodes Matthew: This very rare species may be limited to the lower Bridger, but tentative recognition of the genus in the upper Eocene at Badwater Creek makes this seem improbable.

Trogosus castoridens Leidy: No record later than lower Bridger.

Trogosus hyracoides (Marsh): No record later than lower Bridger.

Trogosus latidens (Marsh): Locality and horizon for the type not known, but well represented in the lower Bridger of the northern part of the basin, also recorded in the upper part of the Cathedral Bluffs tongue.

Tillodon fodiens (Marsh): Known only in the lower Bridger.

Stylinodon mirus Marsh: The locality for the type is not known. One specimen in the NMNH is from the upper Bridger; however, undetermined stylinodont material is known from the lower Bridger.

Metacheiromys marshi Wortman: This species may well be lower Bridger, although two specimens appear uncertain. Simpson (1931a) cites the type as "probably Bridger B at Grizzly Buttes." A referred specimen cited as "probably Bridger C, Dry Creek," may well be from the lower Bridger of Dry Creek in the area shown by Matthew (1909b) as C.

Metacheiromys tatusia Osborn: Possibly a lower Bridger form, but one of the three described specimens (see Simpson 1931a) is from an unknown locality.

Metacheiromys dasypus Osborn: Possibly a lower Bridger form, but the only referred specimen (Yale collection) is from an unknown locality, regarded by Simpson (1931a) as probably B.

Metacheiromys osborni Simpson: The only described specimen is from the upper Bridger.

Tetrapassalus mckennai Simpson: The type from the upper Bridger at Tabernacle Butte is the only known specimen.

Tetrapassalus proius West: The type from the lower Bridger along Sage Creek is the only known specimen.

Thisbemys plicatus A. E. Wood: All the known material is lower Bridger.

Leptotomus parvus A. E. Wood: Known only from the lower Bridger and beds of equivalent age.
Leptotomus bridgerensis A. E. Wood: Restricted to the upper Bridger and beds of equivalent age in the Washakie Basin.

Microparamys minutus R. W. Wilson: Type is believed to be from the lower Bridger but referred specimens are known from both levels.

Microparamys wilsoni A. E. Wood: Type and referred specimen are stated by Wood (1962) to be from the upper Bridger but no localities are given.

Microparamys wyomingensis A. E. Wood: Described from material found in the upper Bridger at Tabernacle Butte, but considered by West (1969a) to be represented in the lower Bridger as well.

Reithroparamys delicatissimus (Leidy): Known in the upper Bridger as well as the lower according to A. E. Wood (1962).

Reithroparamys matthewi A. E. Wood: Although the type is upper Bridger, referred material is from unknown locality.

Pseudotomus hians Cope: Although Matthew (1909b) lists referred material from upper and lower Bridger, A. E. Wood (1962) recognizes only the type which is from Cottonwood Creek and hence probably lower Bridger.

Ischyrotomus horribilis A. E. Wood: Type and referred specimens are from the lower Bridger, as represented in NMNH.

Ischyrotomus oweni A. E. Wood: Type and referred specimen in NMNH are cited by Wood (1962) as upper Bridger north of Twin Buttes. The locality is actually in Bridger $B$. The Princeton specimen cited is from the upper Bridger.

Ischyrotomus superbus (Osborn, Scott, and Speir): Although Matthew (1909b) lists this species as occurring in both upper and lower Bridger, A. E. Wood (1962) recognizes only the type in the hypodigm, which is from the lower beds along Cottonwood Creek.

Mysops minimus Leidy: This species may represent the lower Bridger only; however, Matthew (1909b) as with some other forms has it listed as represented throughout the Bridger. R. W. Wilson (1938) cites one specimen at Yale from an unknown locality.

Sciuravus bridgeri R. W. Wilson: All known specimens are apparently from the lower Bridger, as noted by R. W. Wilson (1938).

Sciuravus (?) rarus R. W. Wilson: Apparently 
known only from the type specimen, which is from an unknown Bridger locality.

Tillomys senex Marsh: Found at Henry's Fork and Tabernacle Butte, but apparently not known from the lower Bridger.

Tillomys (?) parvidens (Marsh): According to R. W. Wilson (1938), material of this species is found in both upper and lower Bridger.

Taxymys (?) progressus R. W. Wilson: The type, evidently the only known specimen, is from an unknown Bridger locality.

Pauromys perditus Troxell: The type of this species, coming from Dry Creek, could be either upper or lower but I suspect it is lower because of the vastly greater area of lower Bridger involved in the Dry Creek drainage on the east side of the basin.

Pauromys schaubi A. E. Wood: The type, the only known specimen, is upper Bridgerian, as the red stratum at Twin Buttes is above the Sage Creek White Layer.

Synoplotherium vorax (Marsh): Apparently represented by only the type specimen, which is from the upper Bridger.

Harpagolestes macrocephalus Wortman: The type and referred specimen in the NMNH are from the lower Bridger. No others are recorded.

Patriofelis ulta Leidy: The type and referred specimens are all from the lower Bridger. One specimen stated by me (1957) to be from low in Bridger $\mathrm{C}$ north of Twin Buttes is actually from Bridger $\mathrm{B}$.

Patriofelis ferox (Marsh): The type is from Henry's Fork and Matthew (1909b) cites all referred Bridger material in the AMNH as from $\mathrm{C}$ or $\mathrm{D}$ although no localities are given. It should be noted, however, that Wortman (1902), Matthew (1909b), and Thorpe (1923) list Limnofelis latidens Marsh as a synonym, the type of which comes from Grizzly Buttes.

Sinopa major Wortman: The type of this species is stated by Wortman to be from Church Buttes. This is doubted by Matthew (1909b) as all AMNH referred material is from Bridger $D$. The NMNH material is also upper Bridger.

Sinopa minor Wortman: The Yale type and referred material in both the AMNH and NMNH are from the lower Bridger. All but one specimen in the Yale collections are from the lower Bridger. The exception is stated by Wortman (1902) to be doubtfully from Henry's Fork.
Sinopa grangeri Matthew: The type and referred materials in the NMNH are all from the lower Bridger. Apparently no other specimens have been recorded.

Tritemnodon agilis (Marsh): The type and cotype at Yale were found at Grizzly Buttes and Church Buttes. Referred material in the AMNH (Matthew, 1909b) and the NMNH are all from the lower Bridger.

Limnocyon verus Marsh: Although the Yale type, the NMNH referred material, and the type of the synonym Limnocyon riparius are from the lower Bridger, Matthew (1909b) cites upper as well as lower Bridger specimens in the AMNH collections; however, he suspects that the upper Bridger material may represent a distinct species.

Thinocyon velox Marsh: Evidently all material of this species in the Yale collections (see Wortman, 1902, and Thorpe, 1923) and the AMNH as well as the NMNH is from the lower Bridger.

Thinocyon medius (Wortman): This may be an upper Bridger species as Matthew (1909b) cites it as represented in C and D but gives no localities. Thorpe (1923) and Denison (1938) also regard it as upper Bridger, but Wortman (1902), while citing the type as from Henry's Fork, says that other specimens were found in the lower part of the deposits. It is possible that Wortman's referred specimens are of a different species.

Thinocyon mustelinus Matthew: Matthew (1909b:300), while erroneously listing this species as Thinocyon "minimus," cites the type as lower Bridger but gives no locality. Denison (1938) also cites the species as lower Bridger, as are the NMNH specimens.

Machaeroides eothen Matthew: This species is relatively rare but the type and paratype are from the lower Bridger, as are two NMNH specimens; however, Matthew (1909b) lists a referred tooth from the upper Bridger but no locality is given. Denison (1938) regards the latter as an advanced variant.

Viverrayus minutus Wortman: This is evidently lower Bridger, although Matthew (1909a) lists the species from both upper and lower Bridger, possibly because the type was from Dry Creek. Later (1909b) he lists the type and all AMNH referred specimens from Bridger B. Wortman (1901) lists Yale referred specimens from Grizzly Buttes.

Viverrayus sicarius Matthew: Matthew (1909b) 
cites all specimens, including the type, as from lower Bridger. Thorpe (1923) notes that specimens of this species in the Yale collections are lower Bridger in age. Those in the NMNH are also lower Bridger.

Miacis parvivorus Cope: The type and all referred specimens in the AMNH, according to Matthew (1909b), are from the lower Bridger. This is true of the NMNH materials also. Thorpe (1923) recognized 8 specimens in the Yale collections but no horizon is mentioned.

Miacis sylvestris (Marsh): Although the Yale type is from the upper Bridger, Matthew (1909b) noted that one of two referred specimens in the AMNH collections was from high in Bridger $\mathbf{B}$.

Miacis hargeri (Wortman): Most specimens were noted by Thorpe (1923) to be from the upper Bridger, including the type, but some he noted were from Grizzly Buttes, Millersville, and Church Buttes.

Oödectes herpestoides Wortman: No locality or horizon is given for the type by Wortman (1901), nor is the horizon cited by Matthew (1909b), although earlier Matthew (1909a) lists the species horizon as Bridger B. Thorpe (1923) notes referred material from Millersville, which is Bridger $\mathbf{B}$.

Oödectes proximus Matthew: Evidently known only from the type, which is from the lower Bridger at Grizzly Buttes.

Uintacyon edax Leidy: The locality and horizon for the type is not known but referred materials in both the Yale (Thorpe, 1923) and the NMNH collections are from the lower Bridger.

Uintacyon vorax Leidy: Although the type was recorded by Leidy as from Henry's Fork, Matthew (1909b) questions this and lists AMNH specimens as from the lower Bridger, as are the NMNH specimens. Wortman (1901) also records a Yale specimen from the lower beds, but Thorpe (1923) cites several Yale specimens without locality data.

Uintacyon jugulans Matthew: Matthew (1909b) cites type and referred materials as from the upper Bridger, as are the NMNH sepcimens. It should be noted, however, that a Yale specimen from the lower Bridger, thought by Wortman (1901) to represent $U$. vorax, is regarded by Thorpe (1923) as being $U$.jugulans.

Uintacyon major Matthew: Matthew (1909b) states that all AMNH specimens came from the upper Bridger, but no localities are given. Thorpe
(1923) refers a lower Bridger specimen to this species.

Vulpavus palustris Marsh: This would appear to be a lower Bridger species as the Yale type as well as referred material in the AMNH (Matthew, 1909b) and the NMNH are from the lower horizon.

Vulpavus profectus Matthew: AMNH type and referred material are lower Bridger, as are the NMNH specimens.

Vulpavus ovatus Matthew: Matthew (1909b) lists referred material as well as the type from the lower Bridger. It is also listed from the lower Bridger by McGrew (1970).

Palaearctonyx meadi Matthew: The type from the base of Twin Buttes is Bridger B, not $\mathrm{C}$ as Matthew (1909b) has listed it. Matthew states that referred material is from Henry's Fork.

Hyopsodus paulus Leidy: I (1968) find statistically that this species is characteristic of the lower Bridger.

Hyopsodus minusculus Leidy: This species is limited to the lower Bridger and is most characteristic of the localities from Millersville to the north (Gazin, 1968).

Hyopsodus marshi Osborn: This very large form appears from my (1968) statistical study to be typical of relatively late upper Bridgerian. The type is stated by Matthew (1909b) as either Twin Buttes or Henry's Fork. He reports that referred specimens are from $\mathrm{C}_{2}$ of Twin Buttes, which would be Bridger B. I question Matthew's referring these to $H$. marsh $i$ as they may well represent large variants of $H$. paulus.

Hyopsodus despiciens Matthew: Characteristic of the upper Bridger according to my (1968) statistical study, and so regarded by Matthew (1909b).

Hyopsodus lepidus Matthew: The relatively small form appears characteristic of the upper Bridger. This is according to my (1968) study as well as Matthew's (1909b).

Uintatherium anceps (Marsh): This species as summarized by Wheeler (1961) is characteristic of the upper Bridger and beds of equivalent age in the Washakie Basin.

Bathyopsis middleswarti Wheeler: This species is characteristic only of the lower Bridger and appears concentrated in the more northerly areas.

Orohippus pumilus (Marsh): Kitts' (1957) review of this species shows it to be limited to the lower part of the Bridger. 
Orohippus agilis Marsh: While of rather limited representation, this species appears to have been found only in the upper Bridger (Kitts, 1957). Matthew (1909b), however, erroneously lists all species of Orohippus as having been found in B, C, and $\mathrm{D}$.

Orohippus major Marsh: Kitts cites the hypodigm of Yale and AMNH specimens as lower Bridger. This is true also of the NMNH specimens.

Orohippus sylvaticus (Leidy): The statement by Kitts (1957) covering the Yale materials as well as the NMNH collection shows this species to be limited to upper Bridger. Matthew (1909a) lists this species as only upper Bridger, and later (1909b), evidently an error, lists referred material in the AMNH as from all levels.

Palaeosyops paludosus Leidy: This titanothere is evidently lower Bridger only, as indicated by Osborn (1929) as well as by the NMNH material.

Palaeosyops major Leidy: This species also appears to be limited to the lower Bridger according to Osborn (1929), as well as by the NMNH materials.

Palaeosyops robustus (Marsh): Limited to the upper Bridger as indicated by Osborn (1929). I have included here also the material of $P$. leidyi, which I cannot distinguish from this species. It is likewise upper Bridger.

Limnohyops laticeps (Marsh): The horizon for the type specimen is not known, but Osborn (1929) cites referred material as from the upper Bridger only.

Limnohyops priscus Osborn: Osborn (1929) cites type and a Princeton referred specimen as lower Bridger. A single specimen in the NMNH is also lower Bridger.

Telmatherium validum Marsh: Osborn recognized only the Yale type as belonging to this species. This specimen as well as the NMNH material is upper Bridger in age.

Telmatherium cultridens (Osborn, Scott, and Speir): This species may well be upper Bridger, but it should be noted that certain specimens cited by Osborn (1929) as Bridger C, or no level given, and one from Twin Buttes are actually uncertain as to horizon. It is not recognized, however, in definitely lower Bridger collestions.

Manteoceras manteoceras (Osborn): This species is fairly well represented and appears to be limited to the upper Bridger and Washakie, as indicated by
Osborn (1929). It has not been reported from Bridger $\mathrm{B}$.

Mesatirhinus megarhinus (Earle): A Washakie species, this form in the Bridger appears to be characteristic of the $\mathrm{C}_{5}$ level according to Osborn (1929), although two specimens are from unknown levels. The NMNH specimens are all upper Bridger.

Mesatirhinus petersoni Osborn: All specimens are cited by Osborn (1929) as upper Bridger or Washakie. One specimen listed only as Bridger $\mathrm{C}_{2}$ may be in question; however, there is no record of the species in the lower Bridger.

Helaletes nanus (Marsh): Recognized in both upper and lower levels of the Bridger. I have included here Helaletes boops, which appears to be a variant recognized only on upper premolars.

Helaletes intermedius (Osborn, Scott, and Speir): If Bridgerian, this relatively rare form would be from the upper level as listed by Matthew (1909a).

Dilophodon minusculus Scott: Evidently upper Bridger as well as Washakie in age, although the type locality is unknown. It has not been recorded from the lower Bridger.

Hyrachyus eximius Leidy: This species would appear to be limited to the upper Bridger, as indicated by H. E. Wood (1934), although I have referred one specimen to it that I found at the top of Bridger $B$, just below the Sage Creek White Layer to the north of Cedar Mountain.

Hyrachyus princeps Marsh: Although Troxell (1922b) cites the type as coming from Fort Bridger, Marsh states that he collected it himself near Henry's Fork. An upper Bridger species, as all the referred material, as noted by H. E. Wood (1934), is upper Bridger in age.

Homacodon vagans Marsh: The type and a plesiotype (after Sinclair, 1914) are both from the upper Bridger, as well as specimens in the NMNH. Matthew (1909a, b), however, lists the form as being both upper and lower Bridger.

Antiacodon venustus Marsh: The type and NMNH referred specimens are from the upper Bridger. Matthew (1909a) lists it only as upper Bridger.

Antiacodon pygmaeus (Cope): Matthew (1909b) lists this species as lower Bridger for both type and referred material in the $\mathrm{AMNH}$, as are referred specimens in the NMNH.

Antiacodon furcatus (Cope): The horizon for the 
type of this species is not certainly known but it may be low in Bridger B. Matthew (1909a) lists the species as lower Bridger, but later (1909b) leaves the type locality blank and lists no referred material in the AMNH.

Helohyus lentus (Marsh): In addition to the type a NMNH specimen is from the upper Bridger, and Matthew (1909b) lists a referred specimen in the AMNH as upper Bridger.

Helohyus validus (Marsh): Although the type is from the upper Bridger near Henry's Fork and McGrew (1959) records specimens from the upper Bridger at Tabernacle Butte, Sinclair (1914) refers to a specimen in the AMNH from lower Bridger on Cottonwood Creek.

Helohyus milleri Sinclair: The recorded material, which apparently includes only the type in the AMNH and a referred specimen in the NMNH is from the upper Bridger.

Lophiohyus alticeps Sinclair: Apparently the only known specimen is the type from Twin Buttes, and as a consequence the level represented may be upper or lower Bridger.

Neodiacodexis emryi Atkins: The only known specimen, the type, is from the upper Bridger at Tabernacle Butte.

\section{Annotated Bibliography}

The following annotated list of references to the Bridger Mammalia includes primarily those papers in which new taxonomic entities are defined or significant contributions are made to the definitions and relationships of the forms represented in the fauna. Also included are those papers which deal with the faunal zoning of the Bridger. Many papers and texts that only repeat or summarize earlier reports and illustrations, or in which descriptions of other faunas include only comparisons or references to Bridger forms, for the most part are not included. Also omitted are references to descriptions of forms now regarded as synonyms unless important information is included.
Abel, Othenio

1922. Lebensbilder aus der Tierwelt der Vorzeit. Pages $\mathrm{i}-\mathrm{vi}+1-643$, figures $1-507,1$ plate. Gustav Fischer: Jena. [While essentially a textbook treatment, Abel's book has a 48-page chapter devoted to the Bridger Basin and vicinity. About half of the 45 figures in this chapter pertain to the Bridger formation and its fauna, including skeletal remains and restorations.]

Allen, Joel A.

1877. Monographs of North America Rodentia: Sciuridae. Pages 631-940 in number 11 in F. V. Hayden, editor, Report of the United States Geological Survey of the Territories. [Included on pages 933939 is a brief statement about each of the known Bridger rodents, which includes characteristics of genera and composition of the type of each species, its size, and where found.]

Atkins, Edward G.

1970. See West, Robert M., and Edward G. Atkins, 1970. Aymard, Auguste

1850. Mammifères fossiles des calcaires du Puy. Annales de la Société d'agriculture, sciences, arts et commerce du Puy, 14:80-86. [The genus Peratherium is named.]

Bonaparte, Carlo L.

1838. Synopsis vertebratorum systematis. Nuovi annali delle scienze naturali (Bologna), 2:105-133. [The family Erinaceidae is named.]
Bradley, Wilmot $\mathbf{H}$.

1964. Geology of the Green River Formation and Associated Eocene Rocks in Southwestern Wyoming and Adjacent Parts of Colorado and Utah. Geological Survey Professional Paper, 496-A:i-iv, Al-A86, figures 1-20, plates 1-3, tables 1-6. [Particularly important in showing the location by plane table survey of the Sage Creek White Layer, as well as the distribution of the Bridger, Green River, and Wasatch formations in the Bridger Basin.]

Butler, Percy M.

1952. The Milk Molars of Perissodactyla, with Remarks on Molar Occlusion. Proceedings of the Zoological Society of London, 121(4):777-817, figures 1-16. [Details of milk molars include discussion and figures of these teeth in Bridger species of Palaeosyops and Hyrachyus.]

1973. Molar Wear Facets of Early Tertiary North American Primates. Symposium of the Fourth International Congress of Primatology, 3:1-27, figures 1-12. [Discussion and figures of wear facets include Bridger species of Notharctus, Omomys, and Washakius.]

Cope, Edward D.

1872a. Descriptions of Some New Vertebrata from the Bridger Group of the Eocene. Proceedings of the American Philosophical Society, 12:460-465. [Also, Paleontological Bulletin, number 1. Original description of the genus and species Mesonyx obtusi- 
dens, and the species Antiacodon pygmaeus as "Lophiotherium pygmaeum."]

1872b. Second Account of New Vertebrata from the Bridger Eocene. Proceedings of the American Philo. sophical Society, 12:466-468. [Also, Palaeontological Bulletin, number 2. Among the forms named as new are Sinopa ("Stypolophus") pungens, new species; Pantolestes longicaudus, new genus and species; and Pseudotomus hians, new genus and species (as an edentate).]

1872c. Third Account of New Vertebrata from the Bridger Eocene of the Wyoming Territory. Proceedings ings of the American Philosophical Society, 12:469472. [Also, Palaeontological Bulletin, number 3. Included is the original description of the new genus and species Miacis parvivorus.]

1872d. Notices of New Vertebrata from the Upper Waters of Bitter Creek, Wyoming Territory. Proceedings of the American Philosophical Society, 12:483-486. [Also, Palaeontological Bulletin, number 6. The genus Synoplotherium is named.]

1872e. On a New Vertebrate Genus from the Northern Part of the Tertiary Basin of Green River. Proceedings of the American Philosophical Society, 12:554. [Also, Palaeontological Bulletin, number 8. Original description of the new genus and species Anaptomorphus aemulus.]

1873a. On Some Eocene Mammals Obtained by Hayden's Geological Survey of 1872. Palaeontological Bulletin, 12:1-6. [Among the various Bridger forms described as new, most of which were later regarded as synonyms, is included the new species Antiacodon furcatus.]

1873b. On the Extinct Vertebrata of the Eocene of $W y$ oming, Observed by the Expedition of 1872, with Notes on the Geology. Pages 545-649, plates 1-6, in F. V. Hayden, editor, Sixth Annual Report of the United States Geological Survey of the Territories for 1872. [Included is detailed description of many of the various Bridger Mammalia recognized in the collections.]

1873c. On the Short-footed Ungulata of the Eocene of Wyoming. Proceedings of the American Philosophical Society, 13:38-74, plates 1-4. [Outlines characters of Bridger species cited for Uintatherium. Compares various skeletal features of Uintatherium with other genera of Dinocerata, and Proboscidea as well.]

1873d. On the Flat-clawed Carnivora of the Eocene of Wyoming. Proceedings of the American Philosophical Society, 13:198-209. [Detailed description and measurements of Mesonyx obtusidens, also of Synoplotherium but based on a Washakie specimen.]

1873e. On the Osteology of the Extinct Tapiroid Hyrachyus. Proceedings of the American Philosophical Society, 13:212-224. [Detailed description with measurements of a skeleton of Hyrachyus eximius.]

1875. On the Supposed Carnivora of the Eocene of the Rocky Mountains. Proceedings of the Academy of
Natural Sciences, Philadelphia, 1875:444-448. [Also, Palaeontological Bulletin, number 20. Names Creodonta and places it along with Tillodontia in the Insectivora. Also, names Mesonychidae, which he considers as representing the true Carnivora.]

1877. Report upon the Extinct Vertebrata Obtained in New Mexico by Parties of the Expedition of 1874 . Part 2 in volume 4 in G. M. Wheeler, editor, Report upon United States Geographical Surveys West of the One Hundredth Meridian. iv + 370 pages, plates 22-83. [Oxyaenidae is named (page 89) and many Bridger mammals are discussed in comparisons.]

1880. On the Genera of Creodonta. Proceedings of the American Philosophical Society, 19:76-82. [Names the family Miacidae.]

1881. On the Vertebrata of the Wind River Eocene Beds of Wyoming. Pages 183-202 in part 8 in volume 6 in F. V. Hayden, editor, Bulletin of United States Geological and Geographical Survey of the Territories. [The genus Bathyopsis is named on a Wind River species.]

1882a. On Uintatherium, Bathmodon and Triisodon. Proceedings of the Academy of Natural Sciences of Philadelphia, 1882:294-300. [Discussion includes description and measurements of lower jaw from Henry's Fork that he refers to Leidy's Uintatherium robustum.]

1882b. Notes on Eocene Mammalia. American Naturalist, 16:522. [The genus Didelphodus is named with the Wasatchian species Deltatherium absarokae as the type.]

1883. On the Mutual Relations of Bunotherian Mammalia. Proceedings of the Academy of Natural Sciences of Philadelphia, 35:77-83. [The families Anaptomorphidae and Esthonychidae are named.]

1884. The Vertebrata of the Tertiary Formations of the West, Book I. In volume 3 in F. V. Hayden, editor, Report of the United States Geological Survey of the Territories, pages $\mathrm{i}-\mathrm{xxxiv}+1-1009$, figures $1-38$, plates 1-75a. [Includes a review of all the known Bridger forms in detail. Also, the family Pantolestidae is named.]

1884-1885. The Amblypoda. American Naturalist, 18:11101121, 1192-1202; 19:40-55, figures 1-35, plate 1 . [Includes discussion and figures of uintatheres from the Bridger (in volume 19).]

1885. The Lemuroidea and Insectivora of the Eocene Period of North America. American Naturalist, 19:457-471, figures 1-18. [Discussion and figures include Bridger forms such as Notharctus tenebrosus, Anaptomorphus aemulus, and Hyopsodus pauIus.]

Dawson, Mary R.

1961. The Skull of Sciurarus nitidus, a Middle Eocene Rodent. Postilla, 53:1-13, plates 1-5. [Description of a nearly complete skull and associated jaw from the Bridger.] 
1962. A Sciuravid Rodent from the Middle Eocene of Wyoming. American Museum Novitates, 2075:1-5, 1 figure. [Bridger sciuravid upper teeth compared with known Bridger forms.]

Dechaseaux, Colette

1958. Encephales de Dinocérates, pages 179-180, 1 figure; Encephales de Périssodactyles fossiles, pages $476-492$, 18 figures; Encephale de Tillodontes, pages 506-507, 2 figures. In volume 2 in tome 6 in Pivetean, Traité de paléontologie. 962 pages, illustrated. Paris: Masson. [Brain casts of Bridger species of Uintatherium, Orohippus, Palaeosyops, and Trogosus, figured and discussed.]

Denison, Robert $\mathbf{H}$.

1938. The Broad Skulled Pseudocreodi. Annals of the New York Academy of Sciences, 37:163-257, figures 1-32. [Several Bridger creodonts included in figures and discussion.]

Dreverman, F.

1913. Sinopa rapax Leidy. Bericht über die Senckenbergische naturforschende Gesellschaft in Frankfurt-am-Main, 44:199-202, 4 figures. [Skull of Sinopa grangeri, the skeleton of Sinopa rapax, and the feet of Hyaenodon etc., figured.]

Earle, Charles

1891a. On a New Species of Palaeosyops Palaeosyops megarhinus. American Naturalist, 25:45-47, 1 figure. [A Washakie specimen is made the type of a species now recognized as Mesatirhinus megarhinus and known also in the Bridger.]

1891b. Palaeosyops and Allied Genera. Proceedings of the Academy of Natural Sciences of Philadelphia, 1891: 105-117, figures 1-2. [Discusses known species of Palaeosyops, Limnohyops, and Telmatherium ("Telmatotherium') as recognized on materials in various museum collections.]

1892. A Memoir upon the Genus Palaeosyops Leidy and Its Allies. Journal of the Academy of Natural Sciences of Philadelphia, series 2, 9 (part 3, article 6): 267-388, plates 10-14. [This includes the genera Palaeosyops, Limnohyops, and "Telmatotherium" (=Telmatherium), principally Bridger material.]

1895. On the Supposed Case of Parallelism in the Genus Palaeosyops. American Naturalist, 29:622-626, plate 27. [Discusses parallelism in Palaeosyops in two lines through the Bridger and Uinta to Titanotherium.]

Edinger, Tilly

1948. Evolution of the Horse Brain. Geological Society of America Memoir 25:i-x, 1-177, figures 1-24, plates 1-4, tables 1-11. [Describes in detail and figures endocranial casts of two Bridger specimens.]

1950. Frontal Sinus Evolution (particularly in Equidae). Bulletin of the Museum of Comparative Zoology, 103 (8):411-496, figures $1-7$ (in text), figures 8-26 in plates 1-9. [Discussion and figures include Bridger Uintatherium and Palaeosyops.]

1956. Objets et résultats de la paléoneurologie. Annales de Paléontologie, 42:97-116, figures 1-18. Paris: Masson et Cie. [Bridger endocranial casts of Thinocyon, Palaeosyops, and Mesatirhinus figured and involved in discussion.]

Emmons, S. F.

1877. Green River Basin. Chapter 2 in volume 2, Descriptive Geology, in Clarence King, editor, United States Geological Exploration of the Fortieth Paral. lel. Pages 191-310, plates 1-9, and frontispiece. [Includes a lithologic description of Bridger as well as other formations in the basin and a list of vertebrate fossils (pages 249-250) described by Marsh and Leidy.]

Emry, Robert J.

1970. A North American Oligocene Pangolin and Other Additions to the Pholidota. Bulletin of the American Museum of Natural History, 142 (6):457-510, figures 1-32. [Includes a discussion of the relationships of Metacheiromys.]

Flower, Wm. Henry

1876. Hunterian Lectures on the Relations of Extinct to Existing Mammalia. Nature, 13:307-308, 327-328, $350-352,387-388,409-410,449-450,487-488$, 513514; 14:11. [Names Uintatheriidae (page 387).]

Gazin, C. Lewis

1934. On the Priority of Specific Names for the Upper Bridger Notharctus. Journal of Mammalogy, 15 (1): 71. [Gave evidence for priority of Notharctus robustior Leidy, 1872, with respect to Notharctus crassus (Marsh), 1872.]

1941. Trailing Extinct Animals in Central Utah and the Bridger Basin of Wyoming. Pages 5-8 in Explorations and Field-Work of the Smithsonian Institution in 1910. Figures 6-10. [Includes description of certain collecting localities and successes in the Bridger, also photographs of some of the localities.]

1946. Machaeroides eothen Matthew, the Sabre-tooth Creodont of the Bridger Eocene. Proceedings of the United National Museum, 96 (3202):335-347, plates 45-46. [Skull, jaws, and certain limb bones described and relationships discussed. Limnocyonidae proposed as a family name.]

1949. A Leptictid Insectivore from the Middle Eocene Bridger Formation of Wyoming. Journal of the Washington Academy of Sciences, $39(7): 220-223$, 1 figure. [Hypictops syntaphus, new genus and species described.]

1953. The Tillodontia: An Early Tertiary Order of Mammals. Smithsonian Miscellaneous Collections, 121 (10): i-vi, 1-110, figures 1-38, plates 1-16. [Includes a revision of the Bridger tillodonts and the new genus Tillodon is named.] 
1955. A Review of the Upper Eocene Artiodactyla of North America. Smithsonian Miscellaneous Collections, $128(8)$ :i-iii, 1-96, plates 1-8, 2 charts. [Evolutionary chart, keys to genera, and discussions of relationships include Bridger forms. The Helohyinae proposed as a subfamily for Marsh's Helohyidae.]

1957. A Skull of the Bridger Middle Eocene Creodont, Patriofelis ulta Leidy. Smithsonian Miscellaneous Collections, $134(8): 1-20$, plates 1-4. [In addition to the description of the skull and jaws found by the University of Utah, there is included a review of the various species of Patriofelis.]

1958. A Review of the Middle and Upper Eocene Primates of North America. Smithsonian Miscellaneous Collections, $136(1): \mathrm{i}-\mathrm{iii}, 1-112,1$ chart, plates 1-14. [Includes a review of all the known Bridger forms, and among the new forms is the Bridger species Anaptomorphus wortmani. An error in the chart shows Smilodectes in the upper Bridger. Types and exceptional specimens figured.]

1959. Paleontological Exploration and Dating of the Early Tertiary Deposits in Basins Adjacent to the Uinta Mountains. Pages 131-138 in Intermountain Association of Petroleum Geologists, 10th Annual Field Conference Guidebook. 1 figure. [Includes a summary of the history of fossil mammal collecting in the Bridger and of zoning as initiated by Matthew. The error in zoning on the east side of the basin is corrected.]

1965. An Endocranial Cast of the Bridger Middle Eocene Primate Smilodectes gracilis. Smithsonian Miscellaneous Collections, $149(4): 1-14$, plates 1-2. [Includes comparisons with Notharctus and European Adapis.]

1968. A Study of the Eocene Condylarthran Mammal Hyopsodus. Smithsonian Miscellaneous Collections, 153 (4):i-iv, 1-90, figures 1-10, plates 1-13. [In addition to a taxonomic review, a morphological study is made of the skeleton based on the Bridger species Hyopsodus paulus.]

Gidley, James W.

1923. Paleocene Primates of the Fort Union, with Discussion of Relationships of Eocene Primates. Proceedings of the United States National Museum, $63(1): 1-38$, plates 1-5. [Includes a restudy of Notharctus based on material described by Gregory.]

Gill, Theodore

1872. Arrangement of the Families of Mammals and Synoptical Tables of Characters of the Subdivisions of Mammals. Smithsonian Miscellaneous Collections, 11 (1):i-vi, 1-98. [Names Dichobunidae and Leptictidae.]

Gilmore, Charles W.

1931. Fossil Hunting in the Bridger Basin of Wyoming. Pages 13-20 in Explorations and Field-Work of the Smithsonian Institution in 1930. Figures 11-16.
[Discussion of collecting localities and outstanding materials recovered. Includes photographs of localities.]

1943. Notes on Two Newly Mounted Fossil Vertebrate Skeletons in the United States National Museum. American Journal of Science, 241:764-766, 1 plate. [One of the skeletons is a nearly complete and articulated Bridger Uintatherium. Discussion includes vertebral formula. Mounted skeleton is illustrated.]

Granger, Walter

1908. A Revision of the American Eocene Horses. Bulletin of the American Museum of Natural History, 24 (15): 221-264, figures 1-5, plates 15-18. [In addition to descriptions and illustrations of types of Bridger Orohippus species, Orohippus progressus is described as new.]

Granger, Walter, and Wm. K. Gregory

1917. A Revision of the Eocene Primates of the Genus Notharctus. Bulletin of the American Museum of Natural History, $37(34): 841-859$, tables 1-2, plates 103-107. [Reviews characters of all species, including Lost Cabin as well as Bridger. Most of the lower Bridger names have since been synonymized and others corrected.]

Gray, John E.

1821. On the Natural Arrangement of Vertebrose Animals. London Medical Repository, 15(1):296-310. [Named Didelphidae and Equidae.]

Gregory, Wm. K.

1913. Relationship of the Tupaiidae and Eocene Lemurs, Especially Notharctus. Bulletin of the Geological Society of America, 24:247-252. [Discussion of Entomolestes as a tupaiid and Notharctus as a lemur.]

1915. On the Relationships of the Eocene Lemur Notharctus to the Adapidae and to Other Primates. Bulletin of the Geological Society of America, 26:419-425. [Gives resumé of earlier interpretations by others, and the anatomical evidence for his own conclusions.]

1920. On the Structure and Relations of Notharctus, an American Eocene Primate. Memoirs of the American Museum of Natural History, new series, $3(2): 49-$ 243, figures 1-84, plates 23-59. [A detailed monograph on Notharctus based essentially on Bridger material, well illustrated and with extensive comparisons with other genera.]

1922. The Origin and Evolution of the Human Dentition. Pages i-xviii, 1-548, 353 figures, 15 plates. Baltimore: Williams and Wilkins Co. [Various Bridger primate dentitions discussed and figured, especially Notharctus.]

1929. The Musculature Anatomy and Restoration of the Titanotheres. In Osborn, 1929, Titanotheres of Ancient Wyoming, Dakota, and Nebraska. United States Geological Survey Monograph, 55:703-725, figures 640-662, plates 43-44. [Muscular anatomy 
of Bridger titanotheres included in discussion and figures.]

Hatcher, J. B.

1895. On a New Species of Diplacodon, with a Discussion of the Relations of That Genus to Telmatotherium. American Naturalist, 29:1084-1090, figures 1-2, plates 38-39. [The genus Manteoceras is named in postscript, based on an upper Eocene species $T$. validens.]

Hayden, F. V.

1872. Preliminary Report of the United States Geological Survey of Wyoming and Portions of Contiguous Teritories (2nd Annual Report). Parts I and II, pages 1-188, figures 1-20. [Includes a popular account of exploration in the Bridger area and description of rocks and formations encountered.]

Hill, Wm. C. Osman

1953. Primates: Comparative Anatomy and Taxonomy, I: Strepsirhini. Pages i-xxiii, 1-798, figures 1-199, plates 1-34. Edinburgh: University Press. [Includes summary descriptions of Bridger species of $A p a$ temys, Aphanolemur, Notharctus, and Uintasorex.]

1955. Primates: Comparative Anatomy and Taxonomy, II: Haplorhini: Tarsioidea. Pages i-xx, 1-347, figures 1-49, plates 1-14. Edinburgh: University Press. [Includes summary descriptions of Bridger species of Anaptomorphus, Hemiacodon, Washakius, and Uintanius.]

Hubrecht, A. A. W.

1896. Die Keimblase von Tarsius ein Hilfsmittel zur schärferen definition gewisser saugethierordnungen. Pages 149-178 in Carl Gegenbaur, Festschrift zum siebenzigsten geburtstage. Figures a-l. [Extensive comparison of Tarsius and Anaptomorphus homunculus. Skull and teeth of latter figured (after Cope).]

King, Clarence

1878. Systematic Geology. Volume 1 in United States Geological Exploration of the Fortieth Parallel. Pages i-xi+1-803, 28 plates, 13 tables. [This includes about 12 pages $(394-405)$ on the geology and topography of the Bridger Eocene (also Washakie) and a list of fossil vertebrates known as of 1878.]

Kitts, David B.

1957. A Revision of the Genus Orohippus (Perissodactyla, Equidae). American Museum Novitates, 1864:1-40, figures 1-9, tables 1-10. [Descriptions include numerical data and illustrations of teeth.]

Koenig, Karl J.

1960. Bridger Formation in the Bridger Basin, Wyoming. Pages 163-168 in Wyoming Geological Association, 15th Annual Field Conference Guidebook. Figures
1-3. [Discussion of the stratigraphy and lithology of the Bridger beds.]

Lane, Henry $\mathbf{H}$.

1932. Variation in Palaeosyops. The University of Kansas Science Bulletin, 20 (18):319-326, 1 table. [Includes discussion of Osborn's stages of development in Palaeosyops.]

Lavocat, René

1958. Condylarthra, pages 1-27, figures 1-29; Dinocerata, pages 164-179, figures 1-18; Tillodontia, pages 499-505, figures 1-9; Taeniodonta, pages 508-521, figures 1-13. In volume 2 in tome 6 in Piveteau, Traité de paléontologie. [Discussion and figures of Bridger Hyopsodus, Uintatherium, Trogosus and Stylinodon.]

Leidy, Joseph

1869a. The Extinct Mammalian Fauna of Dakota and Nebraska, Including an Account of Some Allied Forms from Other Localities, Together with a Synopsis of the Mammalian Remains of North America. Journal of the Academy of Natural Sciences of Philadelphia, series 2, 7:1-472, plates 1-30. [Names Hyaenodontidae.]

1869b. Notice of Some Extinct Vertebrates from Wyoming and Dakota. Proceedings of the Academy of Natural Sciences of Philadelphia, 1869:63-67. [Includes original description of Omomys carteri (new genus and species).]

1870a. [Remarks on Elasmosaurus platyurus and Other Fossil Vertebrates.] Proceedings of the Academy of Natural Sciences of Philadelphia, 1870:9-11. [Includes original description of Patriofelis ulta (new genus and species).]

1870b. [Remarks on a Collection of Fossils from the Western Territories.] Proceedings of the Academy of Natural Sciences of Philadelphia, 1870:109110. [Includes original descriptions of Lophiodon (=Hyrachyus) modestus (new species) and Hyopsodus paulus (new genus and species).]

1870c. [Descriptions of Palaeosyops paludosus, Microsus cuspidatus, and Notharctus tenebrosus.] Proceedings of the Academy of Natural Sciences of Philadelphia, 1870:113-114. [All these are described as new genera and species.]

1870d. [Remarks on a Collection of Fossils from Table Mountain, California (also from the Bridger Basin, Wyoming).] Proceedings of the Academy of Natural Sciences of Philadelphia, 1870:125-127. [The new species Lophiotherium sylvaticum is described (later referred to Orohippus).]

1871a. Report on the Vertebrate Fossils of the Tertiary Formations of the West. Pages 340-370 in part IV in F. V. Hayden, editor, Preliminary Report of the United States Geological Survey of Wyoming and Portions of Contiguous Territories (2nd Annual Report). [The genus Hyrachyus is named on the 
new species Hyrachyus agrestis. Also named is the new species Hyrachyus agrarius. Both species are synonyms of Hyrachyus modesius.]

1871b. Remains of Extinct Mammals from Wyoming. Proceedings of the Academy of Natural Sciences of Philadelphia, 1871:113-116. [Sinopa rapax and Trogosus castoridens named as new genera and species.]

1871c. Remarks on Fossil Vertebrates from Wyoming. American Journal of Sciences, 2:372-373. Proceedings of the Academy of Natural Sciences of Philadelphia, 1871:228-229. [The species Hyrachyus eximius and Palaeosyops major described as new.]

1871d. Notice of Some Extinct Rodents. Proceedings of the Academy of Natural Sciences of Philadelphia, 1871: 230-232. [The genus Paramys and the three species $P$. delicatus, $P$. delicatior, and $P$. delicatissimus are described as new. Also described is the new genus and species Mysops minimus.]

1872a. Remarks on Fossils from Wyoming. Proceedings of the Academy of Natural Sciences of Philadelphia, 1872:19-21. [Microsyops gracilis is described as a new genus and spccics. Another form of Microsyops is described as Palaeacodon verus ( $=M$. elegans).]

1872b. On the Fossil Vertebrates of the Early Tertiary of Wyoming. Pages 353-372 in F. V. Hayden, editor, United States Geological Survey of Montana and Portions of Adjacent Territories (5th Annual Report). [Bridger fauna is discussed by species and included is the original description of the species Notharctus robustior.]

1872c. On Some New Species of Fossil Mammalia from Wyoming. Proceedings of the Academy of Natural Sciences of Philadelphia, 1872:167-169. Also American Journal of Science and Arts (3)4:239-240. [Describes trip to Bridger Basin with Drs. Carter and Corson. Discusses material of Palaeosyops and Hyrachyus found. The genus Uintatherium is described as new on the basis of the new species $U$. robustum. Also describes Uintamastix atrox as new, which together with $U$. robustum are now regarded as synonyms of Uintatherium anceps (Marsh).]

1872d. Remarks on Fossils from Wyoming. Proceedings of the Academy of Natural Sciences of Philadelphia, 1872:277. [The new genus and species Uintacyon edax and a second new species Uintacyon vorax are named.]

1873. Contributions to the Extinct Vertebrate Fauna of the Western Territories. In volume 1 in F. V. Hayden, editor, Report of the United States Geological Survey of the Territories. 358 pages, plates 1-37. [Includes extensive description of the known Bridger Mammalia. Included are original descriptions of Washakius insignis, new genus and species; Hyopsodus minusculus, new species; and Mysops fraternus, new species.]

Lydekker, Richard

1889. [No title.] Pages 889-1474 in volume 2 in Henry A. Nicholson and Richard Lydekker, $A$ Manual of
Paleontology for Use of Students, with a General Introduction on the Principles of Paleontology. 3rd Edition. Edinburgh and London: Wm. Blackwood and Sons. [Names Hyoposodontidae from Trouessart's Hyopsodinae of 1879.]

1904. The Ancestry of the Carnivora. Knowledge, 1 (new series) :61-64, figures 1-5. [Discussion includes characteristics of Miacidae ("Viverravidae"), including Vulpavus, Oödectes, Viverravus (Bridger forms), and Sinopa in relation to modern Carnivora. Vulpavus and Sinopa figured.

1910. Vertebrate Paleontology in 1909. Science Progress, 4:649-676. [Review of Matthew's 1909 memoir on Bridger. Includes discussion of some of Matthew's conclusions and refigures Vulpavus profectus and Limnocyon verus.]

McGrew, Paul O.

1950. Tertiary Vertebrate Fossils of the Green River Basin. Pages 68-74 in Wyoming Geological Association: 5th Annual Field Conference, Southwest Wyoming, Guidebook. 2 figures, 1 map, 1 chart. [Includes brief discussion of history of investigation, characteristic mammal genera, and zoning. Also illustrations of upper teeth of five genera.]

McGrew, Paul O., Jack E. Berman, Max K. Hecht, John M. Hummel, George G. Simpson, and Albert E. Wood

1959. The Geology and Paleontology of the Elk Mountain and Tabernacle Butte Area, Wyoming. Bulletin of the American Museum of Natural History, $117(3): 117-176$, figures 1-27, tables 1-15, plates 50-57. [Scveral localities for upper Bridger forms and two localities of lower Bridger matcrials in the Green River. Described as new species by McGrew are Diacodon bacchanalis and Diacodon edenensis, both since referred to Scenopagus. Also described as new by McGrew is Peratherium knighti. Wood described rodents found in the upper Bridger at Tabernacle Butte. Described as new are Leptotomus parvus, new species; Microparamys, new genus based on Paramys minutus; Microparamys wyoming. ensis, new species; and Thisbemys corrugatus, new genus and species.]

McGrew, Paul O., and Raymond Sullivan

1970. The Stratigraphy and Paleontology of Bridger A. University of Wyoming Contributions to Geology', $9(2): 66-85$, figures 1-16. [A defense of the existence of Bridger $\mathrm{A}$ as distinct from Bridger B.]

McKenna, Malcolm C.

1960. The Geolabidinae, a New Subfamily of Early Cenozoic Erinaccoid Inscctivores. University of California Publications in Geological Sciences, 37(2):131-164, figures 1-6. [In addition to describing the subfamily Geolabidinae under the Erinaceidac, he discussed the Bridger nyctitheriid Myolestes dasypelix, which he placed in his new subfamily. He also described from the Bridger a new genus and species Hypacodon praecursor, which Robinson (1962) synonymized with Centetodon pulcher.] 
1963. Primitive Paleocene and Eocene Apatemyidae (Mammalia, Insectivora) and the Primate-Insectivore Boundary. American Museum Novitates, 2160:1-39, figures 1-5. [Discusses apatemyid position in Insectivora, also recognizes and figures the upper dentition in a Bridger specimen of A patemys.]

McKenna, Malcolm C., Peter Robinson, and

Dwight W. Taylor

1962. Notes on Eocene Mammalia and Mollusca from Tabernacle Butte, Wyoming. American Museum Novitates, 2102:1-33, figures 1-9. [Includes discussion of relationships of various upper Bridger Insectivora from Tabernacle Butte and the presence of a possible chiropteran.]

McKenna, Malcolm C., and George G. Simpson

1959. A New Insectivore from the Middle Eocene of Tabernacle Butte, Wyoming. American Museum Novitates, 1952:1-12, 1 figure, 1 table. [Scenopagus mcgrewi is described as a new genus and species. The species is later synonymized by Robinson with McGrew's species Diacodon edenensis, which is placed in the genus Scenopagus.]

Marsh, Othniel C.

1871a. Notice of Some New Fossil Mammals from the Tertiary Formation. American Journal of Science and Arts, 2:35-44. [Described Uintatherium (as Titanotherium?) anceps, new species; Hyrachyus (as Lophiodon) affinis, new species; Helaletes (as Lophiodon) nanus, new species; Orohippus (as Lophiodon) pumilus, new species; Helohyus (as Elotherium) lentus, new species; Smilodectes (as Hyopsodus) gracilis, new species; Microsyops (as Limnotherium) elegans, new species, all from the Bridger. Also included were other new names, since regarded as synonyms.]

1871b. Notice of Some New Fossil Mammals and Birds from the Tertiary Formations of the West. American Journal of Science and Arts, 2:120-127. [Described Sciuravus nitidus, new genus and species; and Vulpavus palustris, new genus and species, both from the Bridger. Other Bridger names proposed as new have since been regarded as synonyms of earlier names.]

1872. Preliminary Description of New Tertiary Mammals, Parts I-IV. American Journal of Science and Arts, 4:122-128, 202-224, and 504. [Described Limnohyops (as Palaeosyops) laticeps, new species; Telmatherium validum (as $T$. validus), new genus and species; Palaeosyops (as Limnohyus, new genus) robustus, new species; Hyrachyus princeps, new species; Homacodon vagans, new genus and species; Limnocyon verus, new genus and species; Viverrayus gracilis, new genus and species; Miacis (as Harpalodon, new genus) sylvestris, new species; Nyctitherium velox, new genus and species; Scenopagus (as Nyctitherium) priscus, new species; Talpayus nitidus, new genus and species; Patriofelis (as Limnofelis, new genus) ferox, new species; Tritemnodon (as Limnocyon) agilis, new species; Thinocyon velox, new genus and species; Orohippus, new genus for Lophiodon pumilus; Helohyus plicodon, new genus and species; Helohyus (as Thinotherium, new genus) validus (as valudum), new species; Pantolestes (as Anisacodon, new genus) elegans, new species; Centetodon pulcher, new genus and species; Antiacodon venustus, new genus and species; Microsyops (as Bathrodon) annectens, new species; Hemiacodon gracilis, new genus and species; Didelphodus (as Centetodon) altidens, new species; Nyctitherium (as Nyctilestes, new genus) serotinum (as serotinus) new species; Helaletes boops, new genus and species; Pseudotomus (as Paramys) robustus, new species; Tillomys senex, new genus and species; Taxymys lucaris, new genus and species; Tillomys? (as Sciuravus) parvidens, new species; Mysops (as Tillomys) parvus, new species; Apatemys bellus, new genus and species; Apatemys bellulus, new species. Several other new names proposed have since been regarded as synonyms of earlier names.]

1873a. On the Gigantic Fossil Mammals of the Order Dinocerata. American Journal of Science and Arts, 5:117-122, plates 1-2. [Includes discussion of characteristics of Uintatherium (as Tinoceras and Dinoceras) and figures of Bridger skull labeled "Dinoceras mirabilis".]

1873b. Notice of New Tertiary Mammals. American Journal of Science and Arts, 5:407-410, 485-488. [Described Orohippus agilis, new species; Trogosus (as Tillotherium, new genus) hyrachoides, new species; and named Brontotheriidae (as Brontotheridae).]

1874a. Notice of New Equine Mammals from the Tertiary Formation. American Journal of Science and Arts, 7:247-258, 5 figures. [Includes discussion of Orohippus and description of Orohippus major, new species.]

1874b. Notice of New Tertiary Mammals, III. American Journal of Arts and Sciences, 7:531-534. [Includes description of Stylinodon mirus, new genus and species, also Trogosus (as Tillotherium) latidens, new species.]

1875a. New Order of Eocene Mammals. American Journal of Science and Arts, 9:221. [Named the order Tillodontia and the family Stylinodontidae.]

1875b. Notice of New Tertiary Mammals, IV. American Journal of Science and Arts, 9:239-250. [Described as new Tillodon (as Tillotherium) fodiens, new species, from the Bridger, as well as new forms from other formations.]

1876a. Principal Characters of the Dinocerata. American Journal of Science and Arts, 11:163-168, 1 figure. [Description of skull, brain, and other skeletal portions of Uintatherium (as Dinoceras mirabile). Skull figure includes sketch of brain cavity.]

1876b. Principal Characters of the Tillodontia. American Journal of Science and Arts, 11:249-252, plates 8-9. [Description of skull, etc., of Trogosus (as Tillotherium) fodiens, more comprehensive than previously.] 
1876c. Notice of New Tertiary Mammals, V. American Journal of Science and Arts, 12:401-404. [Includes description of Synoplotherium (as Dromocyon) vorax, new species.]

1881. Restoration of Dinoceras mirabile. American Journal of Science, 22:31-32, plate 2. [Discussion and drawing of articulated skeleton of Uintatherium. First printing of a much copied illustration.]

1885. The Gigantic Mammals of the Order Dinocerata. Pages 243-302 in Fifth Annual Report of the United States Geological Survey. Figures 36-137. [Detailed description of the skeleton of Bridger Uinlalherium, under various synonyms of $U$. anceps, and comparisons with other large mammals.]

1886. Dinocerata: A Monograph of an Extinct Order of Gigantic Mammals. Monographs of the United States Geological Survey, 10:i-xviii, 1-243, plates 1-56. [A comprehensive study of the known materials of uintatheres, particularly Bridger, but including Wind River and Washakie forms as well. The skeletal details of Bridger material well illustrated.]

1890. Notice of New Tertiary Mammals. American Journal of Science, 39:523-525. [New genus Limnohyops is described on basis of species Palaeosyops laticeps.]

1894. Description of Tertiary Artiodactyles, American Journal of Science, 48:259-274. [Includes further description, including figures of tooth and foot material, of Homacodon vagans and Helohyus plicodon.]

1897. The Stylinodontia, a Suborder of Eocene Edentates. American Journal of Science, 3:137-146, figures 1-9. [Further description, including figures of teeth, cervical vertebrae, and limb material of Stylinodon mirus.]

Matthew, Wm. D.

1899. A Provisional Classification of the Fresh-water Tertiary of the West. Bulletin of the American Museum of Natural History, 12:19-75. [Bridger species listed by locality. Also, the new genus Palaeictops is named with a Wind River species Ictops bicuspis as the type.]

1906. The Osteology of Sinopa, a Creodont Mammal from the Middle Eocene. Proceedings of the United States National Museum, 30:203-233, figures 1-20, 1 plate. [Detailed description with illustrations of the Bridger skeleton in the National Museum of Natural History. Sinopa grangeri is named as a new species and Tritemnodon is named as a new genus based on the species Limnocyon agilis Marsh.]

1909a. Faunal Lists of the Tertiary Mammalia of the West. Bulletin of the United States Geological Survey, 361:91-138. [Includes listing of Bridger mammals according to occurrence in upper and lower levels. Also includes geologic range of various genera.]

1909b. The Carnivora and Insectivora of the Bridger Basin, Middle Eocene. Memoirs of the American
Museum of Natural History, 9(6):291-567, figures 1-118, plates 42-52. [Comprehensive study of the two orders and includes stratigraphic zoning of the Bridger from $A$ to $E$ with a listing of mammals encountered in each horizon. Mapping errs in the distribution of the Sage Creek White Layer. Among the forms described as new are: Uintasorex paruulus, new genus and species; Trogolemur myodes, new genus and species; Nyctitheriun (as Myolestes, new genus) dasypelix, new species; Entomolestes grangeri, new genus and species; Hyopsodus despiciens, new species; Hyopsodus lepidus, new species; Pantolestes natans, new species; Pantolestes phocipes, new species; Pantolestes inter. medius, new species; Viverravus sicarius, new species; Uintacyon jugulans, new species; Uintacyon ınajor, new species; Oödectes proximus, new species; Vulpavus profectus, new species; Vulpavus ovatus, new species; Palaearctonyx meadi, new genus and species; Thinocyon mustelinus ( $T$. minimus in listing), new species; Machaeroides eothen, new genus and species. Named new family Apatemyidae.]

1910. On the Osteology and Relationships of Paramys, and the Affinities of the Ischyromyidae. Bulletin of the American Museum of Natural History, 28(6): 43-72, figures 1-19. [The genera Ischyrotomus and Leptolomus are described as new subgenera based on upper Eocene species.]

1915. A Revision of the Lower Eocene Wasatch and Wind River Faunas, Part IV: Entelonychia, Primates, Insectivora (part). Bulletin of the American Museum of Natural History, 34(14):429-483, figures 1-52, plate 15. [Bridger forms involved in keys and discussions in this and other parts of the lower Eocene revision. Uintanius is named as a new genus with the new species $U$. turriculorum as the type, a synonym of $U$. ameghini.]

1920. A New Genus of Rodents from the Middle Eocene. Journal of Mammalogy, 1(4):168-169. [The new genus Reithroparamys is named for Paramys delicatissimus.]

Merrill, George P.

1907. Catalogue of the Type and Figured Specimens of Fossils, Minerals, Rocks, and Ores in the Department of Geology, United States National Museum, Part II: Fossil Vertebrates; Fossil Plants; Minerals, Rocks, and Ores. Bulletin of the United Stales National Museum, 53(2):1-370. [Includes in the list the Bridger mammal types in the NMNH with original citations.]

Miller, Gerrit S., Jr., and James W. Gidley

1918. Synopsis of the Supergenerie Groups of Rodents. Journal of the Washington Academy of Sciences, 8(13):431-448. [Names Paramyidae, Cylindrodontidae, and Sciuravidac.]

Osborn, Henry F.

1892. See Osborn and Wortman, 1892.

1898. The Extinct Rhinoceroses. Memoirs of the American 
Museum of Natural History, 1(3):75-164, figures 1-49, plates 12A-20. [Discussion includes features of Hyrachyus agrarius ( $=H$. eximius) as a hyracodont. Also, the skull and skeleton are figured.]

1899. See Matthew, W. D., 1899:47. [Names Manteoceras (as Palaeosyops) manteoceras, new species.]

1900. Oxyaena and Patriofelis Restudied as Terrestrial Creodonts. Bulletin of the American Museum of Natural History, 13(20):269-279, figures 1-8, plates 18-19. [The skeletal features of Bridger Patriofelis are reviewed and illustrated. He refutes Wortman's suggestion that certain Patriofelis characters indicate an aquatic habit.]

1902. American Eocene Primates, and the Supposed Rodent Family Mixodectidae. Bulletin of the American Museum of Natural History, 16(17):169-214, figures $1-40$. [Discussion and illustrations include Bridger primates, hyopsodontids, and microsyopsids. The new Bridger species Hyopsodus marshi is described.]

1904. An Armadillo from the Middle Eocene (Bridger) of North America. Bulletin of the American Museum of Natural History, 20(12):163-165. [Names two new species, Metacheiromys dasypus and Metacheiromys tatusia.]

1908a. New or Little Known Titanotheres from the Eocene and Oligocene. Bulletin of the American Museum of Natural History, 24(32):599-617, figures 1-21. [Among the forms named as new are Limnohyops priscus, new species, and Mesatirhinus petersoni, new genus and species.]

1908b. Coincident Evolution through Rectigradations and Fluctuations (third paper). Science (new series) 27: 749-752, figures 1-3. [Uses Palaeosyops and Orohippus as examples in discussing principles involved in dolychocephaly and brachycephaly. Drawings include skulls and teeth of Palaeosyops and teeth of Orohippus.]

1909. Cenozoic Mammal Horizons of Western North America. Bulletin of the United States Geological Survey, 361:1-90, figures 1-15, plates 1-3. [Includes a three-page section devoted to the Bridger zoning, $A$ to $E$, and faunal characters.]

1929. The Titanotheres of Ancient Wyoming, Dakota, and Nebraska. United States Geological Survey Monograph 55(2 volumes):1-953, figures 1-797, plates 1236. [Includes comprehensive discussion of Bridger titanotheres, including original descriptions. Well illustrated.]

Osborn, Henry F., Wm. B. Scott, and Francis Speir, Jr.

1878. Palaeontological Report of the Princeton Scientific Expedition of 1877. Contributions from the Museum of Geology and Archaeology of Princeton College, 1:1-107, plates A, 1-10. [Description in detail of the materials of the various species obtained in the Bridger beds. Among the forms described as new are Helaletes (as Hyrachyus) intermedius, new species; Ischyrotomus (as Paramys) superbus, new spe. cies; Telmatherium (as Leurocephalus, new genus) cultridens new species; and Parisectolophus (as Helaletes) latidens, new species.]

Osborn, Henry F., and Jacob L. Wortman

1892. Fossil Mammals of the Wahsatch and Wind River Beds: Collection of 1891. Bulletin of the American Museum of Natural History, 4(11):81-147, figures $1-18(+1)$, plate 4. [Discussions and comparisons involve Bridger species, also, the families Microsyopsidae and Helaletidae are named by Osborn.]

1895. Perissodactyls of the Lower Miocene White River Beds. Bulletin of the American Museum of Natural History, 7(12):343-375, figures 1-12, plates 8-11. [There is inserted description with illustrations of skull and teeth of a newly found Bridger specimen of Hyrachyus agrarius ( $=H$. modestus).]

Palmer, Theodore S.

1904. Index Generum Mammalium: A List of the Genera and Families of Mammals. North American Fauna, 23:1-984. [Includes all Bridger genera and family names up to 1904, also the type, author, reference, and derivation of each generic name is given, and the family arrangement.]

Peterson, Olof A.

1919. Report upon the Material Discovered in the Upper Eocene of the Uinta Basin by Earl Douglass in the Years 1908-1909, and by O. A. Peterson in 1912. Annals of the Carnegie Museum, 12(2-4):40-168, figures 1-19, plates 34-47. [Discussions include Bridger forms. New forms named include the family Isectolophidae, and the genus Parisectolophus based on the Bridger species Isectolophus (originally Helaletes) latidens.]

Piveteau, Jean

1961. Carnivora. Pages 641-820 in volume 1 in tome 6 in Traité de paléontologie. Figures 1-203. [Most of the better known Bridger Carnivora are figured and discussed, including endocranial cast of Thinocyon velox.]

Radinsky, Leonard B.

1963. Origin and Early Evolution of North American Tapiroidea. Yale University, Peabody Museum of Natural History Bulletin, 17:1-106, figures 1-21, plates 1-4. [Bridger helaletids and isectolophids included in the study. Included in the lumping of certain genera and of certain species, the genus Parisectolophus, named by Peterson for I. latidens, is placed in synonymy with Isectolophus.]

1967. Hyrachyus, Chasmotherium, and the Early Evolution of the Helaletid Tapiroids. American Museum Novitates, 2313:1-23, figures 1-4, tables 1-5. [Principally concerned with Bridger Hyrachyus eximius and Hyrachyus modestus. Various species are placed in synonymy with one or the other of these two, including certain European forms. The Hyrachyidae is regarded as a subfamily of Helaletidae.]

Robinson, Peter

1957. The Species of Notharctus from the Middle Eocene. 
Postilla (Yale Peabody of Natural History), 28:1-27, figures 1-5, plates 1-2. [The Bridger species of Notharctus are reduced in number and arranged by horizon. Smilodectes (as Notharctus) gracilis is included in the upper Bridger because of its occurrence at Twin Buttes. The level involved is now known to be Bridger B.]

1963. Fused Cervical Vertebrae from the Bridger Formation (Eocene) of Wyoming. University of Colorado Studies, Series in Geology, 1:6-9, 1 figure. [Interpreted as representing an upper Bridger edentate.]

1968a. Talpavus and Entomolestes (Insectivora, Adapisoricidae). American Museum Novitates, 2339:1-7, I figure. [Describes characteristics of the Bridger species Talpavus nitidus and Entomolestes grangeri.]

1968b. Nyctitheriidae (Mammalia, Insectivora) from the Bridger Formation of Wyoming. Contributions to Geology (University of Wyoming), 7(2):129-138, plates I-2. [Review of the genus Nyctitherium includes the species $N$. velox and $N$. serotinum and to these are added $N$. dasypelix the type of $M y o$ lestes. Entomacodon angustidens is placed in synonymy with Nyctitherium serotinum and Entomacodon minutus is regarded as a didelphid. Nyctitherium curtidens is considered a synonym of Scenopagus priscus.]

Saban, Roger

1958. Palaeanodonta, pages 522-533, figures 1-4; Insectivora, pages 822-909, figures 1-37. In volume 2 in tome 6 in Piveteau, Traite de paléontologie. [Some genera of Bridger insectivores discussed and Metacheiromys tatusia figured and discussed.]

Schaub, Samuel

1958. Simplicidentata. Pages 659-818 in volume 2 in tome 6 in Piveteau, Traité de paléontologie. Figures 1283. [Various Bridger genera included in discussion. Bridger Paramys species, Sciuravus nitidus, Taxymys lucaris, and Mysops parvus figured.]

Schlosser, Max

1887. Die Affen, Lemuren, Chiropteren, Insectivoren, Marsupialer, Creodonten, und Carnivoren des europäischen Tertiärs und deren Bezichungen zu ihren lebenden und fossilen aus europäischen Verwandten. Beiträge zur Paläontologie und Geologie österreich-Ungams und des Orients (Wien). 6:1-224, plates 1-5. [Names family Adapisoricidae.]

Scott, Wm. B.

1883. On Desmatotherium and Dilophodon, Two New Eocene Lophiodonts. Contributions from the $E$. $M$. Museum of Geology and Archaeology of Princeton College, Bulletin 3(4):46-53, plate 8. [Includes description of Dilophodon minusculus, new genus and species, and figure of lower jaw.]

1888. On Some New and Little Known Creodonts. Journal of the Academy of Nalural Sciences of Philadelphia (series 2), volume 9, part 2, article 4, pages 155-185, plates 5-7. [Extensive description and figures of skelcton of Mesonyx obtusidens.]
Simpson, George G.

1927. A North American Oligocene Edentate. Annals of the Carnegie Museum, 17(2):283-298, plate 24. [Names the family Epoicotheriidae.]

1928a. A New Mammalian Fauna from the Fort Union of Southern Montana. American Museum Novitates, 297:1-15, figures 1-14. [Names the family Nyctitheriidae.]

1928b. American Eocene Didelphids. American Museum Novitates, 307:1-7, figures 1-5. [Describes the Bridger species Peratherium innominatum.]

1931a. Metacheiromys and the Edentata. Bulletin of the American Museum of Natural History, 59(6):295381, figures 1-23. [Reviews the species of Metacheiromys and their association with other forms in the upper and lower Bridger. Describes in detail the skeleton of Metacheiromys dasypus. Names Metacheiromys osborni, new species.]

1931b. A New Classification of Mammals. Bulletin of the American Museum of Natural History, 59(5): 259293. [Names family Palacoryctidae.]

1940. Studies on the Earliest Primates. Bulletin of the American Museum of Natural History, 77(4):185212 , figures 1-8. [In addition to a discussion of the relationships of early primates, there is included a detailed description of a Bridger skeleton referred to Hemiacodon.]

1945. The Principles of Classification and a Classification of Mammals. Bulletin of the Anerican Museum of Natural History, 85:i-xvi, 1-350. [With regard to the Bridger genera, except for a few amendments and additions, this remains the most logical arrangement.]

1959a. A New Middle Eocene Edentate from Wyoming. American Museum Novitates, 1950:1-8, figures 1-2. [Describes Tetrapassalus mckennai, new genus and species.]

1959b. Two New Records from the Bridger Middle Eocene Tabernacle Butte, Wyoming. American Museum Novitates, 1966:1-5, figures 1-2. [Describes Palaeictops (as Diacodon) bridgeri, new species, and records Viverravus, cf. gracilis.]

Sinclair, Wm. J.

1906. Volcanic Ash in the Bridger Beds of Wyoming. Bulletin of the American Museum of Natural History, 22(15):273-280, plates 35-38. [Describes stratigraphic and lithologic features of the Bridger, although division of formation into lower, middle, and upper does not correspond to zoning of Matthew and Granger.]

1914. A Revision of the Bunodont Artiodactyla of the Middle and Lower Eocene of North America. Bulle. tin of the American Museum of Natural History, 33(21):267-295, figures 1-28. [The Bridger forms are reviewed and illustrated, and described as new are Lophiohyus alticeps, new genus and species, and Helohyus milleri, new species]. 
Stehlin, Hans G., and Samuel Schaub

1951. Die Trigonodontie der Simplicidentaten Nager. Schweizerishche Palaeontologische Abhandlungen, 67:1-385, figures 1-620. [Discussion and figures of dentitions of Sciuravus nitidus, Mysops fraternus, and Taxymys lucaris included.]

Strauss, Wm. L., Jr.

1929. Studies of Primate Ilia. American Journal of Anatomy, 43:403-460, 8 figures. [Detailed study of Notharctus ilium is subject of 4-page appendix.]

Szalay, Frederick S.

1969a. Uintasoricinae, a New Subfamily of Early Tertiary Mammals (?Primates). American Museum Novitates, 2363:1-36, figures 1-25. [The Bridger form Uintasorex parvulus is included in the subfamily, which he regards as part of the Microsyopsidae (as "Microsyopidae').]

1969b. Mixodectidae, Microsyopidae, and the InsectivorePrimate Transition. Bulletin of the American Museum of Natural History, 140(4):193-330, figures 1-28, tables 1-21, plates 17-57. [Various Bridger forms are involved in the study. It is noted that several of the National Museum of Natural History specimens figured are cited incorrectly as to formation or member and with names corresponding to the incorrect level. These are not misplaced legends as only two show the wrong catalog number. As a consequence his criteria for rearrangements and synonymy seem meaningless. The observed errors of fact and the revised determinations are as follows: Plate 34: figures 4-6, number 12138 is Microsyops elegans from the Bridger, not "Microsyops" latidens from the Knight. Plate 34: figures 7-9, no. 12140 is Microsyops gracilis from the Bridger, not "Microsyops" latidens from the Knight. Plate 36: figures 3 and 4, nos. 22110 and 22114 are from the Knight member of the Wasatch, not the New Fork, and which I regard as Cynodontomys latidens rather than Microsyops. Plate 36: figures 11 and 12 are of no. 22108, not 22107, which is from the Knight, not the New Fork, and which I regard as Cynodontomys knightensis rather than "Microsyops" latidens. Plate 37, figures 3-7, nos. 19322 and 22107 are from the Knight, not the New Fork, and which I regard as Cynodontomys knightensis rather than "Microsyops" latidens. Plate 39: figures 9 and 10, no. 17817 I regard as Microsyops schlosseri, not Microsyops annectens. Plate 40: figures 3-5 are of no. 22106, not 22107, and is from the Knight, not the New Fork member of the Wasatch, and which I regard as Cynodontomys knightensis, not "Microsyops” latidens. Plate 47: figures 1-5, no. 13440 I regard as representing Microsyops gracilis from an associated maxilla, not Microsyops elegans. I should also add that on page 248 he has listed "Diacodexis: Gazin, 1952, p. 71" as a synonym of Microsyops. This artiodactyl tooth cannot represent Microsyops.]
Thorpe, Malcolm R.

1923. Notes on the Bridger (Eocene) Carnivora. American Journal of Science 5(3):23-39. [Discusses material and characteristics of various carnivora represented in the Marsh collection.]

Tilney, Frederick

1931. Fossil Brains of Some Early Tertiary Mammals of North America. Bulletin of the Neurological Inst $i$ tute of New York, 1(3):430-505, figures 1-46. [1ncludes description and figures of brains of Bridger Uintatherium, Palaeosyops, and Hyrachyus.]

Trouessart, Edouard-Louis

1879. Catalogue des mammifères vivants et fossiles. Revue et magazine de zoologie pure et appliqué (Paris), series 3, 7:219-285. [Names Notharctidae.]

Troxell, Edward L.

1922a. Helaletes Redefined. American Journal of Science, $3(35): 365-370$, figures 1-3. [Describes skull of Helaletes boops and distinguishes species Helaletes nanus on upper premolars.]

1922b. The Genus Hyrachyus and Its Subgroups. American Journal of Science, 4(5):38-49, figures 1-5, plate 1 . [Review of Bridger species of Hyrachyus.]

1923a. Pauromys perditus, a Small Rodent. American Journal of Science, 5(10):155-156, 1 figure. [Pauromys perditus is described as a new genus and species from the Bridger.]

1923b. The Eocene Rodents Sciuravus and Tillomys. American Journal of Science, 5(32):383-396, figures 1-23. [Reviews and figures dentions of Bridger species of Sciuravus and Tillomys.]

1923c. The Apatemyidae. American Journal of Science, 5(40):503-506, figures 1-6. [Reviews Bridger species of Apatemys and adds Apatemys rodens, new species.]

1923d. A New Marsupial. American Journal of Science, 5(41):507-510, figures 1-4. [Describes the new marsupial Peratherium (as Herpetotherium) marsupium, new species.]

1926. Smilodectes or Notharctus. American Journal of Science, 11:423-428, figures 1-3. [Discusses confusion with regard to the relationships of Smilodectes gracilis, which he includes in Notharctus.]

Van Valen, Leigh

1963. The Origin and Status of the Mammalian Order Tillodontia. Journal of Mammalogy, 44(3):364-373, plates 1-2. [Includes the order Tillodontia in the Condylarthra because he thinks (mistakenly) that Esthonyx looks like the creodont carnivore Claeno. don.]

1966. Deltatheridia, a New Order of Mammals. Bulletin of the American Museum of Natural History, 132(1): 1-17, plates 1-8. [Among the Bridger forms mis. takenly included in the order Deltatheridia are species belonging to the palacoryctid insectivore, Didelphodus; the oxyaenid creodont, Patriofelis; the hyaenodontid creodonts Sinopa and Tritemnodon; and the limnocyonid creodonts Limnocyon, Thinocyon, and Machaeroides.] 
Viret, Jean

1958. Perissodactyla. Pages $368-475$ in volume 2 in tome 6 in Piveteau, Traité de paléontologie. Figures 1-112, plate 1. [Genera of horses, titanotheres, and tapiroids represented in the Bridger are discussed and figured.]

1961. Artiodactyla. Pages 887-1021, 1038-1084 in volume 1 in tome 6 in Piveteau, Traité de paléontologie. Figures 1-119, 136-166. [Includes discussion of some of the Bridger artiodactyles and Homacodon vagans is figured.]

West, Robert M.

1969a. Paramys wyomingensis, a Small Rodent from the Middle Eocene of Wyoming. Journal of Paleontology, 43(1):175-178, figures 1-2. [Regards Wood's Microparamys wyominensis as belonging in the genus Paramys.]

1969b. Biostratigraphy of Fluvial Sediments of the Upper Wasatch Formation in the Northern Green River Basin, Wyoming. Contributions to Geology (University of Wyoming), 8(number 2, part 2):184-196, 5 figures, 1 table. [Refers beds with a Bridgerian fauna, which are in the same depositional basin as the Bridger formation, to the Cathedral Bluffs tongue, which is essentially a late Wasatchian deposit in the Washakie and Great Divide Basins. See Bradley's map (1964) and the map in McGrew et al. (1959), also my report of 1959 (page 135).]

1972. Minimammals and Bridger Biostratigraphy. Society of Vertebrate Paleontology Guidebook (Field Conference on Tertiary Biostratigraphy of Southern and Western Wyoming), pages 40-50, figures 1-3. [Bridger fauna discussed by genera only. Regards local ecology as possibly more significant than vertical zoning.]

1973a. Geology and Mammalian Paleontology of the New Fork-Big Sandy Area, Sublette County, Wyoming. Fieldiana Geology, 29:i-viii, 1-193, figures 1-33, plates 1-16, tables 1-61, sections 1-14. [Includes discussion of Bridger species encountered at various localities. Reference to Robinson concerning occurrence of Smilodectes in the upper Bridger is an error which must result from Matthew's interpretation of zoning at Twin Buttes. Its occurrence there is lower not upper Bridger.]

1973b. Review of North American Eocene and Oligocene Apatemyidae (Mammalia: Insectivora). Special Pub. lications, The Museum, Texas Tech University, 3:1-42, figures 1-20. [Lumps all Bridger and earlier apatemyid genera and species into one form, Apatemys bellus.]

1973c. An Early Middle Eocene Epoicotheriid (Mammalia) from Southwestern Wyoming. Journal of Paleontology, 47(5):929:931, 1 figure. [Describes Tetrapassalus prious, new species, on an indeterminate lower jaw fragment with one spikelike tooth preserved.]
1974. New North American Middle Eocene Nyctithere (Mammalia, Insectivora). Journal of Paleontology, 48(5):983-987, 1 plate. [Names Pontifactor bestiola, new genus and species, from the upper Bridger.]

West, Robert M., and Edward G Atkins

1970. Additional Middle Eocene (Bridgerian) Mammals from Tabernacle Butte, Sublette County, Wyoming. American Museum Novitates, 2404:1-26, figures 1-9, tables 1-2. [Considerable discussion of Phenacodus material thought to occur in beds of Bridgerian age. A new artiodactyl from the upper Bridger, Neodiacodexis emryi, new genus and species, is described by Atkins.]

West, Robert M., and Mary R. Dawson

1973. Fossil Mammals from the Upper Part. of the Cathedral Bluffs Tongue of the Wasatch Formation (Early Bridgerian), Northern Green River Basin, Wyoming. Contributions to Geology (University of Wyoming), 12(1):33-41, figures 1-4. [Reports about 40 species of Bridgerian mammals, mostly rodents from the "Green locality," purported to be from the upper part of the Cathedral Bluffs tongue, but not the same basin of deposition as the true Cathedral Bluffs tongue.]

Wheeler, Walter $\mathrm{H}$.

1961. Revision of the Uintatheres. Yale University, Peabody Museum of Natural History Bulletin, 14:1-iv, 1-93, figures 1-9, plates 1-14. [Reduces the numerous names that have been applied to upper Bridger uintatheres to one, Uintatherium anceps, in the Bridger Basin. Bathyopsis middleswarti, new species, is named for the lower Bridger beds.]

Wilson, Robert W.

1937. Two New Eocene Rodents from the Green River Basin, Wyoming. American Journal of Science, 34: 447-456, figures 1-2. [Describes Microparamys (as Paramys) minutus, new species, from the Bridger, exact locality not known.]

1938. Review of Some Rodent Genera from the Bridger Eocene (Parts I-III). American Journal of Science, 35:123-137, 207-222, 297-304, figures 1-15. [Reviews the genera Sciuravus, Mysops, Tillomys, Taxymys, and Pauromys. Named as new species are Sciuravus bridgeri, Sciuravus? rarus, and Taxymys? progressus.]

1949. Early Tertiary Rodents of North America. Carnegie Institution of Washington Publication, 584: 67-164, figures 1-13. [Discussion of relationships involves known Bridger forms. Also, a chart shows distribution of species between upper and lower levels, but according to the original distribution of the zones according to work of Matthew and Granger.]

Wood, Albert E.

1959a. A New Sciuravid Rodent of the Genus Pauromys from the Eocene of Wyoming. American Museum Novitates, 1978:1-6, 1 figure. [Pauromys schaubi, new species, is described from the red stratum at Twin Buttes (upper Bridger).] 
1959b. See McGrew, Paul O., Jack E. Berman, Max K. Hecht, John M. Hummel, George G. Simpson, and Albert E. Wood, 1959.

1962. Early Tertiary Rodents of the Family Paramyidae. Transactions of the American Philosophical Society, new series, 52(1):1-261, figures 1-91. [A comprehensive description of the known rodents of the Paramyidae. Among forms described as new are the Bridger species Thisbemys plicatus, Leptotomus bridgerensis, Microparamys wilsoni, Reithroparamys matthewi, Ischyrotomus horribilis, and Ischyrotomus oweni.]

Wood, Horace E. II

1927. Some Early Tertiary Rhinoceroses and Hyracodonts. Bulletins of American Paleontology, 13(50):3-105, plates 1-7, tables 1-7. [Discusses Hyrachyus, names family Hyrachyidae.]

1934. Revision of the Hyrachyidae. Bulletin of the American Museum of Natural History, 67(5):181-295, tables 1-6, plates 20-24. [Detailed descriptions of members of the family Hyrachyidae. Recognizes 4 genera and 10 species of Bridger hyrachyids. Names Black's Fork member of the Bridger formation for Bridger $A$ and $B$, and Twin Buttes member for Bridger $\mathrm{C}$ and D.]

Wortman, Jacob L.

1894. Osteology of Patriofelis, a Middle Eocene Creodont. Bulletin of the American Museum of Natural History, 6(5):129-164, figures 1-5, 1 plate. [Detailed description of Bridger material of Patriofelis, with figures of skull and skeleton of $P$. ferox.]
1901-1902. Studies of Eocene Mammalia in the Marsh Collection, Peabody Museum,- Part 1: Carnivora. American Journal of Science, 11:333-348, 437-450; 12:143-154, 193-206, 281-296, 377-382, 421-432; 13: 39-46, 115-128, 197-206, 433-448; 14:17-23; figures $1-99$, 11 plates. [Includes detailed description of Bridger Carnivora with illustrations. Described as new are Harpagolestes macrocephalus, new genus and species; Sinopa minor, new species; Sinopa major, new species; Thinocyon (as Limnocyon) medius, new species; Viverravus minutus, new species; Miacis (as Valpavus) hargeri, new species; and Ö̈dectes herpestoides, new genus and species.]

1903-1904. Studies of Eocene Mammalia in the Marsh Collection, Peabody Museum, Part II: Primates. American Journal of Science, 15:163-176, 399-414, $419-436$; 16:345-368; 17:23-33, 133-140, 203-214; figures 100-148, plates 11-12. [Includes detailed description of known Bridger primates with illustrations. Described as new are Metacheiromys marshi, new genus and species; Microsyops schlosseri, new species; Smilodectes, new genus (for Hyopsodus gracilis); and Uintanius (as Omomys) ameghini, new species.]

Zittel, Karl A. von

1925. Mammalia (revised by Max Schlosser and Sir Arthur Smith Woodward). Volume III in Text-Book of Paleontology. Pages i-viii +1-316, figures 1-374. London: Macmillan and Co. Limited. [Various Bridger genera summarized, some in detail. Some Bridger species figured.] 





\section{Publication in Smithsonian Contributions to Paleobiology}

Manuscripts for serial publications are accepted by the Smithsonian Institution Press, subject to substantive review, only through departments of the various Smithsonian museums. Non-Smithsonian authors should address inquiries to the appropriate department. If submission is invited, the following format requirements of the Press will govern the preparation of copy.

Copy must be typewritten, double-spaced, on one side of standard white bond paper, with $11 / 2 "$ top and left margin, submitted in ribbon copy with a carbon or duplicate, and accom. panied by the original artwork. Duplicate copies of all material, including illustrations, should be retained by the author. There may be several paragraphs to a page, but each page should begin with a new paragraph. Number consecutively all pages, including title page, abstract, text, literature cited, legends, and tables. The minimum length is 30 pages, including typescript and illustrations.

The title should be complete and clear for easy indexing by abstracting services. Taxonomic titles will carry a final line indicating the higher categories to which the taxon is referable: "(Ammonoidea: Goniatitidae)." Include an abstract as an introductory part of the text. Identify the author on the first page of text with an unnumbered footnote that includes his professional mailing address. A table of contents is optional. An index, if required, may be supplied by the author when he returns page proof.

Two headings are used: (1) text heads (boldface in print) for major sections and chapters and (2) paragraph sideheads (caps and small caps in print) for subdivisions. Further headings may be worked out with the editor.

In taxonomic keys, number only the first item of each couplet; if there is only one couplet, omit the number. For easy reference, number also the taxa and their corresponding headings throughout the text; do not incorporate page references in the key.

In synonymy, use the short form (taxon, author, date:page) with a full reference at the end of the paper under "Literature Cited." Begin each taxon at the left margin with subsequent lines indented about three spaces. Within an entry, use a period-dash (.-) to separate each reference. Enclose with square brackets any annotation in, or at the end of, the entry. For references within the text, use the author-date system: "(Jones, 1910)" and "Jones (1910)." If the reference is expanded, abbreviate the data: "Jones (1910:122, pl. 20: fig. 1)."

Simple tabulations in the text (e.g., columns of data) may carry headings or not, but they should not contain rules. Formal tables must be submitted as pages separate from the text, and each table, no matter how large, should be pasted up as a single sheet of copy.

Use the metric system instead of, or in addition to, the English system.

Illustrations (line drawings, maps, photographs, shaded drawings) can be intermixed throughout the printed text. They will be termed Figures and should be numbered consecutively; however, if a group of figures is treated as a single figure, the components should be indicated by lowercase italic letters on the illustration, in the legend, and in text references: "Figure $9 b . "$ If illustrations (usually tone photographs) are printed separately from the text as full pages on a different stock of paper, they will be termed Plates, and individual components should be lettered (Plate $9 b$ ) but may be numbered (Plate 9: figure 2). Never combine the numbering system of text illustrations with that of plate illustrations. Submit all legends on pages separate from the text and not attached to the artwork. An instruction booklet for the preparation of illustrations is available from the Press on request.

In the bibliography (usually called "Literature Cited"), spell out book, journal, and article titles, using initial caps with all words except minor terms such as "and, of, the." For capitalization of titles in foreign languages, follow the national practice of each language. Underscore (for italics) book and journal titles. Use the colon-parentheses system for volume, number, and page citations: "10(2):5-9." Spell out such words as "figures," "plates," "pages."

For free copies of his own paper, a Smithsonian author should indicate his requirements on "Form 36" (submitted to the Press with the manuscript). A non-Smithsonian author will receive 50 free copies; order forms for quantities above this amount with instructions for payment will be supplied when page proof is forwarded. 


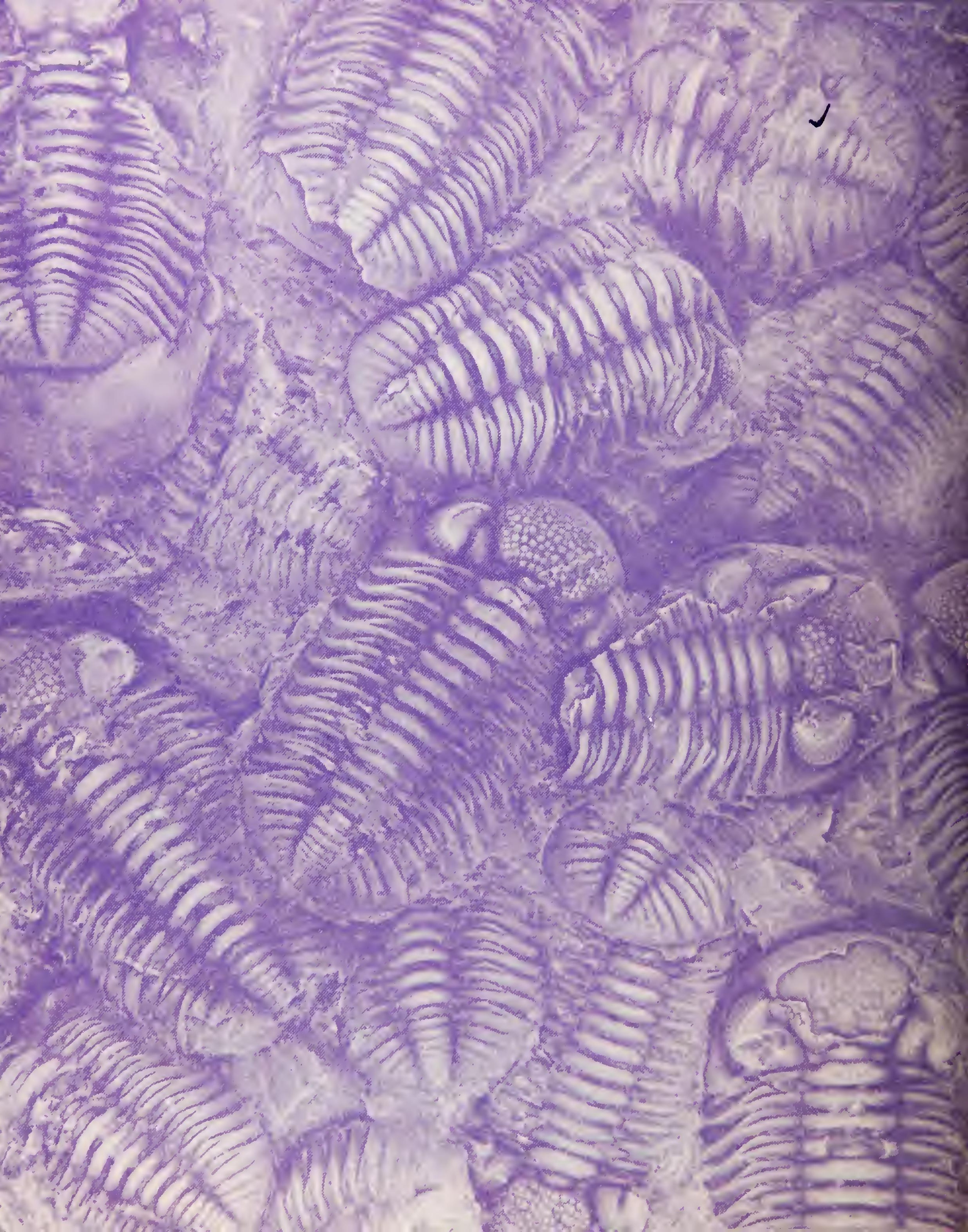

